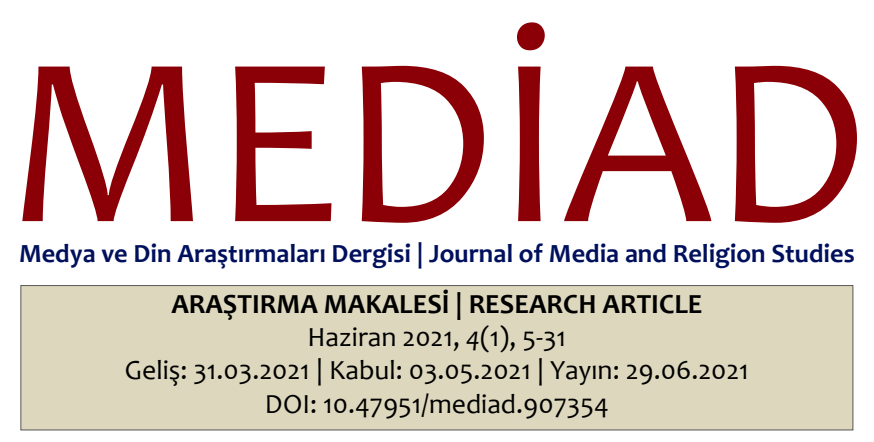

\title{
Nefret Söylemi Pratiği Olarak İslamofobi: Fransa'da Yükselen İslamofobik Söylemlerin Türk Yazılı Basınında Yansıtılma Biçimleri
}

\author{
Şükrü BALCl* \\ Betül KARADENIZ**
}

Öz

Hem İslamofobinin hem de nefret söyleminin insanların zihinlerini etkileyerek yönlendirebilme gücüne sahip olan medya aracılığıyla kitlelere aktarılması; bu olguların meşrulaştııılmasına, yaygınlaştırımasına ve içselleştirilmesine neden olmaktadır. Bu çalışmada İslamofobik söylemlere karşlık olarak medya aracılığıyla nefret söyleminin üretilip üretilmediği ortaya koyulacaktır. Bu doğrultuda çalışmada, 16 Ekim 2020 günü Fransa'da bir öğretmenin başının kesilerek öldürülmesi sonrasında Fransız yetkililerin olayı "Islamcı terör”, saldırganı “islamcı terörist” olarak tanımlamasından sonra İslam'ı ve Müslümanları hedef alan İslamofobik söylemlerin ve yaşanan gelişmelerin Türk yazılı basınında nasıl sunulduğunun ortaya koyulması amaçlanmaktadır. Araştırmanın örneklemine dâhil edilen Cumhuriyet, Hürriyet, Sabah, Sözcü, Yeni Şafak gazetelerinin, olay sonrası yaşanan gelişmelere yönelik yaptıkları tüm baş sayfa haberlerin nefret söylemi bağlamında ele alınmıștır. Haberleri, başlıkları, içerikleri, görselleri ve gazetelerin olaya ilişkin bakış açıları Teun van Dijk'ın söylem analizi yöntemiyle analiz edilmiştir. Araştırma sonucunda, gazetelerin İslamofobik temelli durumları aktarırken; ardalan ve bağlam bilgisini detaylandırmadığı, haberlerin içeriklerini tek bir kişinin konuya dair yaptığı değerlendirmeler üzerinden inşa ettiği ve nefret söylemi üretiminde bulunduğu tespit edilmiştir.

Anahtar Kelimeler: İslamofobi, Nefret Söylemi, Haber Söylemi, Gazete Yayın Politikaları

\section{Islamophobia as a Practice of Hate Speech: The Ways of Reflecting Islamophobic Discourses Rising in France in the Turkish Written Press}

\begin{abstract}
The transmission of both Islamophobia and hate speech to the masses through the media, which has the power to influence and direct people's minds, causes these facts to be legitimized, disseminated, and internalized. In this context, the study will reveal whether hate speech is produced through the media in response to Islamophobic speech. This study, after the decapitation of a teacher in France on October 16, 2020, and the French authorities' definition of the incident as "Islamist terror" and the aggressor as "Islamist terrorist", how Islamophobic rhetoric and developments targeting Islam and Muslims were presented in the Turkish print media. It is aimed to be revealed. All front-page news about developments after the incident by Cumhuriyet, Hürriyet, Sabah, Sözcü, Yeni Safak newspapers included in the sample of the study were discussed in the context of hate speech. The headlines, contents, visuals of the news, and the perspectives of the newspapers regarding the event were analyzed using Teun van Dijk's discourse analysis method. As a result of the research, while reporting the Islamophobic-based situations of the newspapers; It was determined that he did not elaborate the background and context information, he built the contents of the news based on the evaluations made by a single person on the subject and produced hate speech.
\end{abstract}

Keywords: Islamophobia, Hate Speech, News Discourse, Newspaper Publication Policies

ATIF: Balcı, Ş. ve Karadeniz, B. (2021). Nefret söylemi pratiği olarak İslamofobi: Fransa'da yükselen İslamofobik söylemlerin Türk yazılı basınında yansıtılma biçimleri. Medya ve Din Araştırmaları Dergisi (MEDIAD), 4(1), s. 5-31.

* Prof. Dr., Selçuk Üniversitesi, sukrubalci@selcuk.edu.tr| orcid.org/0000-0002-0477-0622

** Arş. Gör., Trabzon Üniversitesi, betulkaradeniz@trabzon.edu.tr| orcid.org/0000-0002-1066-1684 


\section{Giriş}

Medya, insanların manipüle edilerek zihinlerinin yönlendirilmesinde önemli bir etkiye sahiptir. Medya sahip olduğu bu etki doğrultusunda insanların neye, nasıl ve niçin ihtiyaç duyduklarını öğretmekte, dikte etmekte, şartlandırmaktadır; neye, nasıl ve niçin tepki gösterip göstermeyecekleri konusunda yönlendirmekle birlikte neyin kendileri için yararlı veya zararlı olduğuna karar vermekte ve bunu derhal onların zihinlerine şııınga etmek için çaba göstermektedir (Karaşahan, 1994, s. 12). Bu durumun farkında olan egemen güçler ise medya mecraları aracılığıyla kitleleri kendi çıkarları doğrultusunda yönlendirmeye çalışmaktadır. Gündelik yaşamlarının dışındaki dünyadan medyanın aktardığı bilgiler doğrultusunda haberdar olan kitleler ise egemen güç odaklarının çıkarları doğrultusunda yeniden kurgulanmış olan gerçeklik ve bu gerçekliğin inşa ettiği yeni dünya tasviri ile karşılaşmaktadır. Bu bağlamda egemen güç odakları, medya 'şeytanı' sayesinde gerçekleştirdikleri psikolojik ve kültürel operasyonlar temelinde, adeta kitlelerin beyinlerini yıkayarak yeni bir kimlik inşa etmeye çabalamaktadır (Yıldız, 1994, s. 4). Bu çaba doğrultusunda egemen güç odakları, insanların algılarını medyanın çeșitli konular hakkında sunduğu imgeler temelinde biçimlendirmeye, zihinlerini kontrol etmeye ve hükmetmeye çalışmaktadır. Medyanın kitlelere sunduğu imgelerin İslamofobi ve nefret söylemi temelinde şekillenmesi ise toplum içerisinde "biz" ve "onlar" çatışmasının sürekli olarak yeniden inşa edilmesine ve meşrulaştırılmasına neden olmaktadır. Bu bağlamda önemli bir mücadele alanı olan medya, ötekileştirdiği grubun insani değerini inkâr ederek, onlara uygulanan şiddet ve aşağılayıcı davranışların meşrulaştırılabilmesine yol açmaktadır (İnceoğlu, 2012, s. 17). Bu çerçevede toplum içerisinde ötekileştirilmiş insanlara ya da gruplara yönelik önyargıları körükleyen söylemsel pratiklerin medya aracılığıyla kitlelere sunulması nefret söyleminin etkisini arttırmaktadır (Gölcü, Bal ve Karadeniz, 2019; Gölcü ve Dağlı, 2017). Benzer şekilde İslam'a ve Müslümanlara yönelik nedensiz bir korkuyu içeren İslamofobinin artmasında ve kitlelere aktarılmasında medyanın kullandığı söylemsel pratikler ve bu pratiklerin toplum içerisindeki yansıması önemli rol oynamaktadır.

İslam dinine ve Müslümanlara yönelik sert konuşmalardan daha fazlasını içeren İslamofobi, ırkçlık, yabancı düşmanlığı ve diğer insanlıktan çıkarma biçimleriyle derinlemesine bağlantılıdır ve genellikle hâkim güç yapılarını sürdürmek isteyenlere hizmet etmektedir (Abadi, 2018, s. 5). Bu durum ise İslam dinine ve Müslümanlara ait gerçekliklerin, egemen güç odaklarının çıkarları doğrultusunda yeniden şekillendirilmesine yol açmaktadır. İslam'a ve Müslümanlara yönelik inşa edilen gerçekliklerin toplum içerisindeki yansıması ise farklı şekillerde ortaya çıkmaktadır. Bu temelde İslamofobi, Müslümanların yaşamlarının tüm yönlerini etkileyen bir yapıya sahip olmakla birlikte farklı şekillerde meydana gelmektedir: Müslümanlara yönelik istismar, şiddet ve saldırılar; camilere, ìslam merkezlerine ve Müslüman mezarlıklarına saldırı; mal ve hizmetlerin dağıtımında, eğitim, istihdam ve barınmada ayrımclık; kamu kurumlarındaki Müslümanlara karşı hüküm ve saygı eksikliği (Allen, 2010, s. 5). Ayrıca İslamofobi, Müslümanları potansiyel terör saldırıları tehlikesiyle özdeşleştiren bir algı ve tepkiye de yol açmaktadır (Furlanetto ve Mehring, 2020, s. 2). Çünkü terör sözcüğü insanların zihinlerine en trajik ve acımasız boyutuyla kazınırken, diğer yandan terör dendiğinde neredeyse hemen hemen herkesin aklına gelen ve ustalıkla benimsetilen bir diğer kelime ise “íslam'dır (Samur, 2017, s. 159). İslam'ın ve Müslümanların “terör” gibi sözcükler ile tanımlanmasında ve hedef haline getirilmesinde medyada kullanılan dil ve söylem pratiklerinin yanı sıra İslamofobiyi besleyen çeşitli görüntülerin yayınlanması da bu süreçte belirleyici rol oynamaktadır. Kitleleri manipüle etme ve yönlendirme gücüne sahip olan medyanın İslamofobi ve nefret söylemi temelinde şekillendirilmesi ise hedef alınan kişi ya da gruplara yönelik tahammülsüzlüğün artarak devam etmesinde ve zaman içerisine nefret suçuna giden yolun açılmasında bir araç olarak doğrudan ya da dolaylı bir şekilde kullanılabilmektedir. Bu kapsamda çalışmanın temel amacını, 16 Ekim 
2020 tarihinde Fransa'da bir öğretmenin başının kesilerek öldürülmesi sonrasında olayın "İslami terör” olarak nitelendirilmesi ile birlikte Fransa'da yükselen İslamofobik söylemlerin Türk yazılı basınında nasıl ve hangi söylemsel pratikler çerçevesinde ele alındığının ortaya koyulması oluşturmaktadır. Bu doğrultuda Cumhuriyet, Hürriyet, Sabah, Sözcü ve Yeni Şafak gazetelerinde yer alan haberler nefret söylemi bağlamında ele alınarak Teun van Dijk'ın söylem analizi yöntemi ile incelenmiştir.

\section{Bir Kavram Olarak İslamofobi}

İslamofobi en basit ifade ile "islam korkusu" anlamına gelmektedir. Bu kavram İslam hakkında bir şeyden korkmak anlamına gelen "islam" ve "fobi" kelimelerinden oluşmaktadır ve Batı kültürünü tehdit edecek bir İslam görüşünü temsil etmektedir (Gata ve Bayhaqy, 2020, s. 1819). İslamofobi temelde sebepleri olmayan mantıksız İslam korkusu anlamına gelmekle birlikte asıl amacı hepsinden nefret etmek temelinde şekillenmektedir (Saeed, 2019, s. 2). İslamofobi olgusu, İslam dininin diğer kültürlerle hiçbir ortak değeri olmadığı, Batı'dan aşağı olduğu ve bir dinden ziyade şiddet içeren bir siyasi ideoloji olduğu şeklindeki önyargilı algıyı içermektedir (Yilmaz, 2016, s. 19). Köklü bir geçmişe sahip olan İslamofobi olgusunun ortaya çıkışı, İslam dininin ilk yıllarına kadar götürülebilirse de, daha kabul görecek bir değerlendirmeyle İslam toplumlarının Batı Hıristiyan milletlerle karşılaşması ve askeri-siyasi bir güç olarak uluslararası alanda kendini göstermesi ile birlikte görülmeye başlanmıştır (Gökmen, 2010, s. 14). Anti-i̇slamizm ve İslamofobinin ana bir mesele haline gelmesi, çok-dinli ve çok-kültürlü Batılı toplumlarda Müslüman gruplarla yerleşik toplumlar arasında bir gerilim yaratması ise 11 Eylül saldırılarının hemen arkasından meydana gelmiştir (Canatan, 2017, s. 88). İslamofobi kavramı, 11 Eylül saldırılarından sonra Müslümanlara yapılan fiili ve entelektüel saldırıları ifade etmek amacıyla yaygın bir kullanım alanına kavuşmaya başlamıştır (Er ve Ataman, 2008, s. 755).

Bir kavram olarak İslamofobi kelimesinin kullanımının Runnymede Trust adlı kuruluşun 1997 yılında "Islamophobia: A Challenge for Us All” adıyla yayımladığı raporda bahsedildiği genel olarak kabul edilen bir görüştür. Bu raporda İslamofobi kavramı, sekiz kategori altında tanımlanan bir kavram olarak ifade edilmiştir. Bunlar; (1) İslami kültürler ve Müslümanlar bir bütün olarak görülmektedir. (2) İslami kültürler, diğer kültürlerden büyük ölçüde farklı olarak değerlendirilir ve diğer kültürleri etkilemedikleri gibi diğer kültürlerden de etkilenmezler. (3) İslam dinine ait olan kültür Batı'da alt kültür (barbar, akıldışı, ilkel, cinsiyetçi) olarak görülmektedir. (4) İslam dini, şiddet yanlısı, terörü destekleyen, saldırgan ve medeniyetler çatışması yapan bir din olarak idrak edilmektedir. (5) İslam dini, siyasi veya askeri avantaj sağlamak amacıyla kullanılan bir siyasal ideoloji şeklinde değerlendirilmektedir. (6) Müslümanların Batı'ya yönelik yaptıkları eleştiriler, derhal reddedilmekte ve kabul edilmemektedir. (7) İslam dinini hedef alan düşmanlık, Müslümanlara yönelik ayrımcı uygulamaları haklı göstermek için kullanılmaktadır. (8) İslamofobi normaldir ve Anti-Müslüman düşmanlığı doğal bir durum olarak kabul edilmektedir (The Runnymede Trust, 1997, s. 4)

İslamofobi, İslâm dinine ve bu dinin mensuplarına karşı kendi varlıklarını tehdit ettikleri gerekçesiyle tedirginlik duyma ve korku yaşama anlamından daha fazlasını içermektedir (Yapıcı ve Yapıcı, 2017, s. 11). Bu bağlamda İslamofobi kavramını yalnızca Müslümanlardan duyulan korku gibi patolojik bir duruma indirgemeden dini ırkçılıktan, Müslüman düşmanlığına hatta İslam karşıtlığı/düşmanlığına kadar geniş bir bakış açısıyla değerlendirmeli, düşünmeli ve ayrımcılığın, ötekileştirmenin, dışlamanın, tahammülsüzlüğün, aşağılamanın bir başka biçimi olarak ele alınması gerekmektedir (Bezci, 2017, s. 8). İslâm düşmanlığının söylemini ve anlayışını ifade etmek üzere kullanılan İslamofobi sözcüğü ile Müslümanlara yönelik 
nefret suçlarından tacize ve kamusal alanda her türlü ayrımcılık ve dışlamadan fiziki saldırı ve sözlü eyleme kadar şiddet suçlarının hafifletilmesi hatta meşrulaştırılmasının dili sürekli bir şekilde yeniden inşa edilmektedir (Bodur, 2017, s. 73). İslam düşmanlı̆̆ı birçok alanda karşımıza çıkmaktadır: Müslümanlara yönelik hakaret içerikli ifade biçimlerinden şiddet eylemlerine, çalışma hayatındaki ayrımcılıktan başörtüsü ve burka gibi simgesel ayrımcılığa, ibadet özgürlüğünün kısıtlanmasından camilere yönelik çeşitli saldırılara, Müslümanların kurduğu okul, dernek ve vakıflara yönelik kontrollerin artırılmasından ve sıkılaştırılmasından, Müslüman ülkelerden Avrupa'ya doğru olan göç hareketlerine karşı önlemler almaya kadar pek çok alanda meydana gelmektedir (Kepenek, 2017, s. 137).

Geçmișten günümüze İslamofobinin sürekli olarak üretilmesinde ve etkisini gün geçtikçe arttırmasında Sajid'e (2005) göre, bir dizi bağlamsal faktörler önemli rol oynamaktadır. Bu bağlamsal faktörlerden ilki, sığınmacıların ve sığınma talebinde bulunanların büyük bir kısmının Müslüman olmasıdır. Mültecilerin şeytanlaştırılması ile birlikte çoğu kez Müslümanlara yönelik kodlanmış bir saldırı ortaya çıkmaktadır: çünkü “Müslüman”, “sığınmacı”, “mülteci”, "göçmen” gibi sözcükler popüler hayal gücünde eşanlamlı ve birbiri ile değiştirilebilir hale gelmektedir. íkinci bağlamsal faktör, başta sol-medya olmak üzere medyada ifade edilen dine ilişkin şüpheci, laik ve belirsiz bakıştır. Bu bakış sadece İslam’a karşı değil, tüm dinlere yöneliktir. Ancak Müslümanlar kamusal platformlara daha az nüfuz ve daha az erişime sahip olduklarından saldırılar çok daha zararlı olmaktadır. Üçüncü bağlamsal faktör ise Birleşik Krallık'ta ve çoğu Batı ülkesinde, dünyadaki çeşitli çatışma durumlarına yönelik uygulanan dış politikadır. Örneğin Birleşik Krallık hükümeti Müslüman olmayanlara, Müslümanlara karşı taraftar gibi görünmekte ve "Müslüman" ve "terörist" terimlerinin eş anlamlı olduğu görüşünü kabul etmektedir.

İslamofobi, İslam dinine aidiyet belirtilerine (gerçek veya varsayılan) dayalı ve biçimleri ulusal bağlama ve tarihsel döneme göre değişen sosyal bir ırklaşma sürecini oluşturmaktadır (Hajjat, 2020, s. 2). Bu sürecin ulusal bağlama ve tarihsel döneme göre farklılaşmasında ise günümüz dünyasında medya önemli rol oynamaktadır. Yani İslamofobiyi besleyen temel sebeplerden birini, medya yoluyla Batı'da anlatılan İslam Dini ve Müslüman tipi imajı oluşturmaktadır (Kahraman, 2012, s. 190). İslam dininin diğer dinlere karşı tahammülü olmayan ve bu bağlamda yaşam hakkı tanımayan, savaşçı ve şiddet içerikli bir din olduğu yönünde basılı ve görsel medyada çeşitli içeriklerde yayınlar yapılması sonrasında İslam hakkında doğru ve yeterli düzeyde bilgi sahibi olmayan gayrimüslim insanların bu yayınlardan etkilenmeleri ise İslamofobi'ye neden olmaktadır (Kınık ve illter, 2019, s. 967). 11 Eylül saldırılarından sonra İslamofobi kavramı, başta ABD ve Avrupa ülkelerinde olmak üzere İslam ve Müslüman karşıtı tepkilerin/tutumların artarak birleştiği ortak bir paydayı temsil eden bir kavram olarak yaygın bir şekilde kullanılmaktadır (Türkan, 2015, s. 23). Amerika ve Avrupa'da özellikle 11 Eylül saldırıları sonrasında söylemsel bir nitelik kazanan İslamofobi'nin oluşumunda ve yaygın bir şekilde kullanılmasında birçok etkenin etkin ve belirleyici rol oynadığı ve bu etkenler arasında da medyanın bulunduğu genel bir görüş olarak ön plana çıkmaktadır (Göksu ve Saygilı, 2012, s. 92).

Sonuç olarak 11 Eylül saldırıları sonrasında İslâm'ın baskıcı bir din ideolojisi olarak şiddet ve terör yanlısı olduğu düşüncesi çeşitli pratikler aracılığıyla yaygın bir söylem haline gelmiştir ve televizyon ekranlarından devlet dairelerine, okullardan internete kadar her şey, bu konu hakkında görüş bildirip yargıda bulunma aracına dönüşmüştür (Kalın, 2003, s. 1). Bu bağlamda İslamofobi olgusunun tarihsel kökenleri geçmişe dayanmakla birlikte 11 Eylül saldırılarından sonra İslam'a ve Müslümanlara yönelik bitmek tükenmez düşmanlık hızla tırmanışa geçmeye başlamıştır. Batı medyasında "biz" ve "onlar" ikilisi 11 Eylül saldırılarından sonra görünür hale gelmiştir ve bu saldırılar ile birlikte Müslüman topluluğu dünya çapında özellikle de Batı'da terörizmden sorumlu olarak tas- 
vir edilmeye başlanmıştır (Basit, 2018, s. 20). Bu tırmanışın temelinde İslam'a ve Müslümanlara karşı medya aracılığıyla üretilen ve kitlelere aktarılan yersiz korkunun sürekli olarak pompalanması önemli rol oynamaktadır. İslam ve Müslümanlar hakkındaki gerçekler, egemen güç odaklarının çıkarları doğrultusunda medya aracılığıyla manipüle edilerek kitlelere aktarılmakta ve İslam'a ve Müslümanlara yönelik bilinçli bir şekilde algı üretimi yapılmaktadır. Bu algı üretimi ile birlikte İslam dini ve Müslümanlar "öteki” olarak inşa edilerek nefret söylemi ve nefret suçunun hedefi haline getirilmektedir.

\section{Bir Söylem Türü Olarak Nefret Söylemi}

Nefret söyleminin evrensel olarak kabul edilmiş standart bir tanımı yoktur. Bunun her şeyden önce temel nedenlerinden birisi etik ve yasal çıkarımlarla ilgili tanımların temelinin her zaman tartışmalı olmasıdır; ikincisi ise nefret teriminin temelde duygusal bir kavram olması ve bu durumun onu öznel yorumlamaya açık hale getirmesidir (Isasi ve Juanatey, 2016, s. 4). Bu bağlamda nefret söylemini tanımlamak ve anlamak kolay değildir. Nefret söyleminin kapsamına dair bir belirsizlik söz konusu olmakla birlikte nefret söylemi “ırk, milliyet, etnik köken, etnik-dinsel kimlik, memleket, din, cinsiyet, cinsel kimlik dâhil olmak üzere belirli bir zeminde bir kişiye veya bir gruba karşı nefret veya önyargı aşılayabilen veya kışkırtabilen konuşma veya ifade" (Obeler ve Connelly, 2014, s. 118), "gerçek veya algılanan doğuștan gelen özelliklerinden bazıları nedeniyle bir kişiye veya bir grup insana yönelik önyargılı, düşmanca, kötü niyetli bir konuşma" (Cohen-Almagor, 2018, s. 672) "bir kişiye veya topluma karşı nefret, şiddet veya ayrımcılığın yayılmasına neden olan, teşvik eden veya kışkırtan herhangi bir ifade" (Chaudhari, Parseja ve Patyal, 2020, s. 940) gibi farklı şekillerde tanımlanmaktadır. Uluslararası alanda yaygın olarak kabul edilen yasal bir tanımı ise Avrupa Konseyi Bakanlar Komitesi tarafından kabul edilen 1997 tarih ve R (97) 20 sayılı tavsiye kararında yer almaktadır. Bu kararda nefret söylemi “Irkçı nefreti, yabancı düşmanlığını, Yahudi düşmanlığını veya azınlıklara, göçmenlere ve göçmen kökenli insanlara yönelik saldırgan ulusalcılık ve etnik merkezcilik, ayrımcılık ve düşmanlık şeklinde ifadesini bulan, dinsel hoşgörüsüzlük dâhil olmak üzere hoşgörüsüzlüğe dayalı başka nefret biçimlerini yayan, kışkırtan, teşvik eden veya meşrulaştıran her türlü ifade biçimidir” (Weber, 2009, s. 3) şeklinde açıklanmaktadır. Bu noktada nefret söylemi konsensüse ulaşmayı hedefleyen bir ifade biçimi olmaktan ziyade, belirli bir gruba yöneltilmiş baskın olma, onu etkisizleştirme ve ona yönelik sözel ya da fiziksel şiddeti teşvik etme hâlini işaret eden bir kavram olarak ifade edilebilir (Kuş, 2021, s. 113).

Nefret söylemi, hedef gruplar arasında acıya neden olan şiddet içeren bir dil$\operatorname{dir}$ (Bilewicz ve Soral, 2020, s. 5). Bu dilin toplum içerisinde kabul görmesi ve yaygınlaşması ise azınlıkta olan gruplara yönelik eşitsiz muamelenin kolaylaşmasına ve artmasına neden olmaktadır. Bu durum bir kişiye ya da gruba karşı nefretin, şiddetin veya ayrımcılığın daha da körüklenmesine, kışkırtılmasına ve teşvik edilmesine yol açmaktadır. Söylem pratiklerinden biri olan nefret söyleminin üretilmesinde kendinden/biz olarak kurulan aidiyetten farklı olana yönelik tahammülsüzlük çerçevesinde üretilen veya kurgulanan olumsuz etiketlemeler, stereotipler, önyargılar ve çeşitli ayrımcılık uygulamaları rol oynamaktadır (Tunçay, 2017, s. 43). Nefret söyleminin kişi veya gruplar üzerinde bıraktığı zarar ise nefret içerikli ifadelerin zaman içerisinde birikerek çoğalması ve toplu olarak görünür olmaya başlaması ile ortaya çıkmaktadır. Nefret söyleminin çoğalması ve kabul görmesi ise toplum içerisinde azınlıkta olan gruplara karşı empatinin azalmasını etkilemektedir ve sonuç olarak ayrımcı eylemleri, suiistimalleri ve çeşitli türlerdeki şiddet içeren eylemleri haklı çıkarmak için verimli bir zeminin oluşturulmasına yol açmaktadır (Isasi ve Juanatey, 2016, s. 7) 
Nefret söyleminin inşa edilmesinde stigma (damgalama), stereotipler (kalıpyargılar), önyargılar, ayrımcılık ve ötekileștirme gibi unsurlar belirleyici rol oynamaktadır (Karadeniz, 2020, s. 38). Bu unsurlar, toplumsal normların dışında kalan birey ya da grupların nefret dilinin hedefi haline gelmesine, ötekileştirilmesine ve zaman içerisinde nefret suçunun hedefi haline gelmesine neden olmaktadır. Bu bağlamda toplum içerisinde azınlıkta olan gruplara yönelik sistematik bir şekilde nefret söyleminin körüklenmesinde, yaygınlaştırılmasında ve içselleştirilmesinde ise kavramın görünenden çok görünmeyen yüzü etkili olmaktadır. Yani söylenenlerden çok söylenmeyenler, normal, rasyonel ve mantıklı görünen ifadeler nefret söyleminin tespit edilmesini zorlaştırmaktadır (İnceoğlu, 2012, s. 17). Bu belirsizlik durumu ise toplum içerisinde dezavantajlı olarak nitelendirilen bireylere ya da gruplara yönelik "biz" ve "onlar" karşıtlığının çeşitli şekillerde inşa edilmesini kolaylaştırmaktadır. Bu temelde insanlar ırkları, dilleri, cinsiyetleri, cinsel yönelimleri, dinleri, etnik kökenleri gibi özelliklerden dolayı ötekileştirilerek nefret dilinin nesnesi haline gelmekte ve toplumsal yapı içerisinde sessizleștirilmektedir. Nefret söyleminin medya aracilığıyla toplum içerisinde cinsel kimlikleri, inanışları, dilleri gibi faktörlerden dolayı dezavantajlı olarak nitelendirilen kişi ya da gruplara yönelmesi ise "biz" ve "öteki” karşıtlığının sistematik bir şekilde sürekli olarak yeniden üretilmesine ve meşrulaştırılmasına neden olmaktadır. İnsanlar sahip oldukları kimliklerinden dolayı egemen çoğunluğun içerisinde ötekileştirilerek toplum içerisinde dışlanmaya, yok sayılmaya başlamaktadır. Bu durumun bir yansımasını ise 11 Eylül saldırıları sonrasında özellikle İslam dinini ve Müslümanları hedef alan ifade biçimlerinde görmek mümkündür. 11 Eylül saldırılarından İslam dinine mensup olanların sorumlu tutulması ile birlikte İslam dini ve Müslümanlar nefret söyleminin hedefi haline gelmiştir. Bu durum İslam dinine ve Müslümanlara karşı yapay bir korku olarak ifade edilen İslamofobi ile kendisi göstermektedir. İslam dini ve bu dinin mensupları, İslamofobik ve bazı İslam karşıtı anlatıların yaygınlaştırııması sonucunda nefret suçlarına, şiddete ve hatta terörist ideolojilere ve terör saldırılarına maruz kalabilmektedir (Fırıncı, 2020, s. 95). Sonuç olarak nefret söylemi günümüz dünyasında halen varlığını sürdürmektedir ve etnik temizlik, soykırım, katliam, zorunlu göç veya sistematik cinsel şiddet gibi hallerle toplumların gündemini meşgul eden ayrımcılık ve yabancı düşmanlığının söylemsel biçimlerden biri olarak varlığını korumaktadır (Sarı, 2015, s. 43).

\section{Medyada Nefret Söylemi ve İslamofobi}

Günümüz dünyası medya mecraları etrafında şekillenmektedir. Çünkü iletişim teknolojilerinde yaşanan değişim ve dönüşüm ile birlikte medya mecraları hayatımızın vazgeçilmez bir parçası haline gelmiştir. Bu mecralardaki yenilikler ve kolaylıklar ise insan hayatını birçok farklı şekilde etkilemeye başlamıştır. Bu etkilerin başında ise medyanın insanların zihinlerini düzenleyerek kitleleri kendi bakış açısı doğrultusunda yönlendirebilme gücüne sahip olması gelmektedir. Fiziki savaşların önemini kaybederek kelimelerin savaşına dönüştüğü günümüz dünyasında medya, bütün heybetiyle istediği konuda istediği türden manipülasyon yaparak istediği konularda insanları ikna edebilme gücünü elinde bulundurmaktadır (Yel, 2018, s. 6). Bu doğrultuda medya gücünü elinde bulunduran egemen güç odakları ise kendi çıkarlarına paralel olarak hem medya metinlerinin önem derecesini belirlemekte, hem de sistematik bir yapı içerisinde neyi-nerede vereceklerine karar vermektedirler (Özkaya, 1994, s. 6). Bu bağlamda medya, insanları kendi aleyhinde kararlar alabilecek, kendi çıkarlarına ters düşebilecek bir şekilde hareket edebilecek biçimde manipüle edebilme gücüne sahiptir; yani halkın kendi çıkarlarını değil, belli bir zümrenin çıkarlarını koruyup kollama ve devam ettirme yönünde yine aynı halkın desteğini sağlamayı başarabilmektedir (Karaşahan, 1994, s. 11).

Insanları etkileme ve yönlendirme gücüne sahip olan medya, etnik ve ırk ilişkileri konusundaki yaygın rızanın üretiminde gerekli olan sembolik kaynakların kontrolünü elinde bulundurması nedeniyle kamuoyundaki ayrımcı-ırkçı kanı ve görüşleri yaygınlaş- 
tırma, meşrulaştırma ve yeniden üretme sürecinde de önemli bir rol oynamaktadır (Köker ve Doğanay, 2010, s. 98). Bu çerçevede medya, toplum içerisinde azınlıkta olan gruplara yönelik olumlu ve olumsuz algıların benimsetilmesinde ustalıkla kullanılabilmektedir. Bu bağlamda medyanın, toplum içerisinde dezavantajlı grupların önyargılar temelinde değerlendirilmesine, ayrımcılığa uğramasında, nefret söyleminin hedefi haline gelmesinde önemli bir etkiye sahip olduğu söylenebilir. Bu durum ise tarihsel olarak ayrımcılığa uğrayan toplulukların, sıklıkla önyargı, hakaret, suç ve hatta zarar verici sonuçları olan şiddet eylemleri için çağrıların hedefi haline gelmesine yol açmaktadır (Cotik, et al., 2020). Medyanın toplumdaki dezavantajı olarak nitelendirilen gruplar üzerindeki yansımasını ise nefret söylemi ve İslamofobi üretiminin bu mecralar aracılığıyla sürekli olarak yeniden üretilmesi ve yaygınlaştırılması şeklinde görmek mümkündür.

İslam'ı ve Müslümanları hedef alan olumsuz söylemlerin artmasının ve geniş kitlelere yayılmasının en mühim nedenlerinden birisi medyadır. Medya kullandığı dil ve söylem pratikleri aracılığıyla Batı dünyasında ve özellikle Avrupa'da, İslam dinine ve Müslümanlara yönelik olarak takınılan olumsuz algı, düşünce, tutum ve davranışların yaratılmasında ve yaygınlaştııımasında en büyük rolü oynamaktadır (Arslan, 2019, s. 14). Çünkü medyada kullanılan dil ve söylem pratikleri aracılığıyla İslam dininin ve Müslümanların olumsuz bir biçimde tasvir edilmesi, İslam'a ve Müslümanlara yönelik bakış açısının "ötekileştirme" temelinde şekillenmesine neden olmaktadır. Bunun temelinde ise Batılı kitle medyasının İslamofobik yaklaşım ve tavırları “konuşma özgürlüğü” adı altında etkin bir şekilde meşrulaştırması yatmaktadır (Buehler, 2014, s. 131). İslamofobik yaklaşımların konuşma özgürlüğü temelinde meşrulaştırılması ise biz ve onlar dilinin İslam dini ve Müslümanlar çerçevesinde inşa edilmesinde belirleyici rol oynamaktadır. Bu dilin sürekli olarak üretilmesinde ve yaygınlaştırılmasında ise medya mecraları ön plana çıkmaktadır.

11 Eylül saldırılarının ardından medya anlatıları ile İslam dinini ve Müslümanları hedef alan ve alt yapısı "korku" ve "terör" ile doldurulan bir kültür inşa edilmektedir. Bu kültürün inşa edilmesinde ise meydana gelen herhangi bir terör saldırısının İslam dini ve Müslümanlar ile ilişkilendirilmesi ve bunların Müslümanları genelleyecek bir şekilde medya aracılı̆̆ıyla kitlelere aktarılması belirleyici rol oynamaktadır. Bu durumun ortaya çıkmasında ise ABD'de ve Avrupa'da yaşanan bazı terör saldırılarından sonra medyada yapılan yayınlar aracılığıyla İslam dinine ve Müslümanlara yönelik önyargıların inşa edilmesi etkili olmaktadır. Bu yayınlarda İslam dini ve Müslümanlar özellikle şiddet ve terör konuları ile ilişkilendirilerek tasvir edilmekte, İslam dini ve Müslümanlar hakkında yapılan yalan/sahte haberler ile İslam dini ve Müslümanlar hakkındaki gerçekler çarpıtılarak kitlere aktarılmaktadır. Bu durum ise İslam dini ve Müslümanlar hakkında yeterli bilgiye sahip olmayan insanların zihinlerinde İslamofobik algıların oluşmasına neden olmaktadır. Daha genel bir ifade ile tanımlayacak olursak basılı ve görsel medyada İslam dininin diğer dinlere yaşam hakkı tanımayan, savaşçı ve şiddet içerikli bir din olduğu yönünde çeşitli yayınlar yapılması ve yapılan bu yayınlar sonrasında İslam hakkında doğru ve yeterli düzeyde bilgi sahibi olmayan gayrimüslim bireylerin bu yayınlardan etkilenmeleri ise İslamofobinin ortaya çıkmasına neden olmaktadır (Kınık ve iltter, 2019, s. 967).

İslam dininin ve Müslümanların ötekileştirilmesinde ve nefret dilinin nesnesi haline gelmesinde önemli bir etkiye sahip olan medya aracılığıyla İslam dini ve Müslümanlar tehditkâr bir kalabalık olarak resmedilmekte ve küresel bir tehdit olarak sunulmaktadır. Bu temelde isslamofobi her zaman belirgin bir şekilde Müslüman nefreti içeren nefret söylemi ile karşımıza çıkmamakta, çoğu zaman medya dilinin elverdiği ölçüde daha kurnazca ve zekice yapılmaktadır (Yel, 2018, s. 
7). Bu durumun yansıması ise medya metinlerinde kullanılan dil ve söylem pratiklerinde belirginleşmektedir. Medyada yer alan İslamofobik mesajlar incelendiğinde, medyanın insanlara; İslamiyet'in şiddet dini olduğu, kılıçla, zorla benimsetilmeye çalışıldığı, Müslümanların gerici, barbar, terörist, istismarcı bir yapısının olduğu, Müslüman göçmenlerin sürekli olaylara karıştığı, Batının yaşam standartlarını tehdit ettiği, değerlerinden uzaklaştırdığı, refah seviyesini düşürdüğü, bu sebeplerle korkulması, dışlanması gereken bir yapısının olduğu mesajlarını sistematik bir şekilde ve sürekli olarak verdiği görülmektedir (Koçer ve Yazıcı, 2018, s. 192).

\section{Araştırmanın Amacı ve Kapsamı}

Bu çalışmada, 16 Ekim 2020 tarihinde Fransa'da bir öğretmenin basın ve düşünce özgürlüğü konusunu öğrencilerine anlatmak için Charlie Hebdo dergisinde çıkan $\mathrm{Hz}$. Muhammed'in karikatürlerini gösterdiği gerekçesiyle başının kesilerek öldürülmesi sonrasında Fransa Cumhurbaşkanı Emmanuel Macron'un söz konusu olayı “islamcı bir terörist saldırı" olarak nitelendirmesi ve ardından İslam dinini ve Müslümanları hedef alan İslamofobik söylemlerin ve yaşanan gelişmelerin ülkemizdeki medya kuruluşlarında ele alınış biçimlerinin nefret söylemi bağlamında ortaya koyulması amaçlanmıştır. Çalışma kapsamında, farklı eksenlerde yayın yapan medya kuruluşlarının Fransa'da yaşanan olay sonrasında İslam'ı ve Müslümanları hedef alan İslamofobik söylemleri ve yaşanan gelişmeleri haberleştirme sürecinde, nefret söylemi pratiklerinin haber dili ve söylemi üzerine yansıması ele alınmıştır. Çalışmada araştırmanın evrenini, Türkiye'de yayınlanan gazeteler oluşturmaktadır. Araştırmanın örneklemini, birbirinden farklı yayın politikalarına sahip olan Cumhuriyet, Hürriyet, Sabah, Sözcü, Yeni Şafak gazetelerinin 24 Ekim - 2 Kasım 2020 tarihleri arasında yayınlanan nüshalarındaki söz konusu İslamofobik söylemler ile Türkiye ve Fransa arasında yaşanan gelişmelere ilişkin haberler oluşturmaktadır. Çalışma, gazetelerin vitrin sayfası olarak nitelendirilen baş sayfalarındaki söz konusu olaya ve yaşanan gelişmelere yönelik haberler ile sınırlandırılmıştır.

\section{Araștırmanın Yöntemi}

Çalışmada, bu araştırmanın konusunu oluşturan söz konusu olay sonrasında İslam'ı ve Müslümanları hedef alan İslamofobik söylemlerin, Fransa ve Türkiye arasında yaşanan gelişmelerin basında yer alan haberler üzerinden nasıl aktarıldığı, Teun van Dijk'ın (1988a; 1988b) söylem analizi yöntemi kullanılarak incelenmiştir. Söz konusu İslamofobik söylemler ve yaşanan gelișmeler ardından basında yer alan haberlere, nefret söylemi bağlamında bakılmıştır. İnceleme, Teun van Dijk'ın makro ve mikro olmak üzere iki bölüm temelinde sistematikleştirdiği söylem analizi yöntemi ile yapılmıştır. Makro çözümleme kendi içerisinde tematik ve şematik çözümleme olmak üzere iki alt başlık altında incelenmektedir. Tematik çözümlemede haberlerin başlıkları, üst başlıkları, haber girişleri, spotlarına yönelik bir çözümleme yapılmaktadır. Şematik çözümlemede ise ardalan ve bağlam bilgisi gibi yapıların çözümlenmesinin yanı sıra habere konu olan olayın ele alıış biçimi, haber kaynakları, olayın taraflarına ait görüşlerin nasıl sunulduğuna yönelik bir değerlendirme de bulunulmaktadır. Mikro çözümleme düzeyinde ise haberlerin sentaktik çözümlemesi, kelime seçimleri, kelimeler arası uyum, cümlelerin ve kelimelerin birbirleri arasındaki ilişki biçimine yönelik bir çözümleme yapılmaktadır (Şeker ve Şeker, 2011; Özer, 2011; İnal, 1996; van Dijk, 1997). Çalışmanın zaman sınırlılığı, araştırmanın konusunu oluşturan söz konusu söylemler ve yaşanan gelişmelerin haberleştirildiği ilk bir hafta (24 Ekim - 2 Kasım 2020 tarihleri arası) olarak belirlenmiştir. Ayrıca araştırma, gazetelerin en çok okunan ve dikkat çeken baş sayfalarında konuyla ilgili yayınladıkları haberler ile sınırlandırılmıştır.

\section{Bulgular ve Yorum}

Aşağıdaki kısımda, araştırmanın örneklemine dâhil edilen Cumhuriyet, Hürriyet, Sabah, Sözcü, Yeni Şafak gazetelerinin, olay sonrası yaşanan gelişmelere yönelik yaptıkları tüm baş sayfa haberleri nefret söylemi bağlamında ele alınmaktadır. 


\section{Cumhuriyet Gazetesi}

Cumhuriyet gazetesi 26 Ekim tarihli sayısında Fransa'da İslam karşıtı söylemlerin artması sonrasında yașanan gelișmeleri “Türkiye-Fransa Gerilimi Büyüyor” başlıklı bir haber ile aktarmıştır. Haberde tematik olarak spot ve ara başlıklar kullanılmamıştır. Haberin içeriğinde Cumhurbaşkanı Recep Tayyip Erdoğan'ın, Fransa Cumhurbaşkanı Emmanuel Macron'a yönelik ifadeleri ve bu ifadelere gelen tepkilere yer verilmiștir. Haberde, Türkiye ve Fransa arasında yaşanan gerginliğin Cumhurbaşkanı Recep Tayyip Erdoğan'ın ifadeleri ile birlikte daha da arttığına ve bu ifadelerin hoş karşılanmadığına yönelik bir vurgu ön plana çıkarılmıştır. Haberin tematik çözümlemesinde, Cumhurbaşkanı Erdoğan'ın Fransa Cumhurbaşkanı Macron'u hedef alan açıklamalarından sonra Türkiye ve Fransa arasındaki gerilimin arttığına dair bir anlatının ön plana çıkarıldığı ve haberin söylemsel çerçevesinin bu anlatıyı destekleyecek şekilde inşa edildiği gözlenmiştir. Haberde aktarılan konunun geri planı hakkında aydınlatıcı bilgilere yer verilmemiştir ve Cumhurbaşkanı Erdoğan'ın ifadeleri bağlamından kopartılarak aktarılmıştır. Ayrıca gazete, habere konu olayın taraflarından Cumhurbaşkanı Erdoğan'ın ve AB Dış îlişkiler Yüksek Temsilcisi Borrell'in ifadelerine yer verirken, Borrell'in Cumhurbaşkanı Erdoğan'a yönelik ifadelerini durum tanımlaması olarak ön plana çıkarmıştır. Haberde, Cumhurbaşkanı Erdoğan'ın ve Fransa Cumhurbaşkanı Emmanuel Macron'un birbirlerine sırtlarını dönmüş ve birbirlerinden uzaklaşırken çekilen fotoğrafı kullanılarak manşetteki "Türkiye-Fransa Gerilimi Büyüyor” ifadesi retoriksel açıdan desteklenmiştir. Haberin mikro yapısına bakıldığında ise gazetenin Fransa ve Türkiye arasında yaşanan süreci "gerilim” olarak nitelendirdiği görülmüştür. Haberde kısa ve net ifadeler tercih edilmiş olmakla birlikte "paylaştı”, “yorumladı” gibi edilgen yapılı cümleler kullanılmıştır. Fransa ve Türkiye arasında yaşanan süreci “gerilim” olarak adlandıran gazetenin, bu durumun sorumlusu olarak Cumhurbaşkanı Erdoğan'ı tercih ettiği kelime ve cümle grupları ile ön plana çıkardığı gözlenmiştir. Bu bağlamda gazetenin manşetinde ön plana çıkan "gerilim” tanımlamasının, haberin içeriğinde "Cumhurbaşkanı Erdoğan'ın, Fransa Cumhurbaşkanı Macron'u hedef almasıyla başlayan gerilim artıyor”, “Dün Macron'a ve Wilders'a sert tepki gösteren Erdoğan” gibi ifadeler ile birbirini tamamlayan bir yapıda inşa edildiği belirlenmiştir.

Cumhuriyet gazetesinin 28 Ekim tarihli sayısında gelişmeler, “Boykot Türkiye'yi AB'den Uzaklaştırır” başlığı altında küçük bir haber ile aktarılmıştır. Haberin içeriğinde Avrupa Komisyonu'nun Cumhurbaşkanı Erdoğan'ın Fransız ürünlerine boykot çağrısının, Türkiye'yi AB'den daha da uzaklaştıracağına yönelik açıklamalarına yer verilmiştir. Bu bağlamda haberin söylemsel çerçevesi, haber kaynağı olarak kullanılan Avrupa Komisyonu'nun açıklamaları üzerinden inşa edilmiştir. Ancak gazetenin bu açıklamaları tırnak işareti kullanmadan aktardığı gözlenmiştir. Haberin tematik çözümlemesine göre haberde, Cumhurbaşkanı Erdoğan'ın Fransız ürünlerini boykot çağrısının Türkiye'nin Avrupa Birliği'ne katılım sürecinden daha da uzaklaştırdığına yönelik bir tema ön plana çıkarılmıştır. Haberde tematik olarak spot ve ara bașlıklar kullanılmazken, konuya dair ardalan ve bağlam bilgisine de yer verilmediği, haberi retoriksel açıdan güçlendirecek herhangi bir görselin de kullanılmadığı görülmüştür. Haberin mikro analizine göre Türkiye ve Fransa arasında yaşanan gelişmeler, edilgen yapılı tek bir cümle ile aktarılmıştır. Haberde Cumhurbaşkanı Erdoğan'ın “boykot çağrısı”nda bulunduğu bilgisi ön plana çıkarılmıştır. Bu bağlamda haberin manşetinde ve içeriğinde "boykot" kelimesinin vurgulandığı gözlenmiştir.

30 Ekim tarihli Cumhuriyet gazetesinde, “Fransa'da Terör Vahşeti” başlıklı küçük bir habere yer verilmiştir. Tematik olarak spot ve ara başlıkların kullanılmadığı haberin içeriğinde, Hz. Muhammed karikatürüyle başlayan gerginlik devam ederken Fransa'da bir kiliseye bıçaklı saldırı düzenlendiği, üç kişinin öldüğü, bir saldırga- 
nın vurulduğu ve Fransa'nın Suudi Arabistan Elçiliği'ne de saldırı girișimi olduğu bilgisi aktarılmıştır. Saldırının gerekçelerine ve arka planına yer verilmediği haberde, gazetenin saldırıyı manşette "terör vahşeti" olarak tanımlarken, haberin içeriğinde ise daha çok "saldırı" olarak ifade ettiği, saldırıyı gerçekleştiren kişiyi ise "saldırgan" olarak tanımladığı görülmüştür. Haberde, bir binanın önünde kalabalık insan gruplarının olduğu bir fotoğraf tercih edilmiştir ve tüm haber bu fotoğrafın üstüne küçük bir şekilde yerleştirilmiştir. Haberde kullanılan fotoğraf ile haberin içeriğinde aktarılan bilgilerin retoriksel açıdan desteklenmediği görülmekle birlikte haberde kullanılan görselin kaynağı olarak “AFP" nin belirtildiği gözlenmiştir. Haberin mikro analizine göre, gazetenin olayı manşetinde "terör vahşeti", haberin içeriğinde de "bıçaklı saldırı", "terör saldırısı" olarak tanımladığı görülmüştür. Bu bağlamda gazetenin haberin söylemsel çerçevesini destekleyecek ifade biçimlerini tercih ettiği ve bu temelde bütüncül bir söylem inşa etmeye çalıştığı gözlenmiştir. Kısa ve net ifadelerin tercih edildiği haberde genel olarak "başı kesildi”, "bir saldırgan vuruldu”, “... saldırı girişimi oldu” gibi edilgen yapılı cümleler kullanılmıştır. Ayrıca gazetenin $\mathrm{Hz}$. Muhammed'e yönelik yapılan karikatür ile başlayan süreci “gerginlik” olarak tanımladığı da dikkat çekmektedir.

\section{Hürriyet Gazetesi}

Hürriyet gazetesi 25 Ekim tarihli sayısında Fransa'da İslam'ı ve Müslümanları hedef alan söylemler sonrasında yaşanan gelişmeleri, “Macron'un Tedaviye ìhtiyacı Var" başlığı altında sayfanın en altında küçük bir haber ile vermiştir. Haberin spotunda, Cumhurbaşkanı Recep Tayyip Erdoğan'ın Fransız Cumhurbaşkanı Emmanuel Macron'a çok sert tepki gösterdiği ifade edilirken, bu ifadeler haberin içeriğinde detaylandırımıştır. Tematik olarak ara başıkların kullanılmadığı haberin içeriğinde, Cumhurbaşkanı Erdoğan'ın Fransa Cumhurbaşkanı Macron'a yönelik değerlendirmeleri tırnak işareti kullanılarak aktarılmıştır. Gazetenin haberin içeriğinde Erdoğan'ın ifadelerini tırnak işareti kullanarak aktardığı görülürken, manşette ise tırnak işareti kullanmadan Erdoğan'ın ifadelerini içselleştirerek aktardığı görülmüştür. Cumhurbaşkanı Erdoğan'ın Macron'a yönelik değerlendirmeleri üzerinden durum tanımlamasının yapıldığı haberde, konunun esas gerekçelerinin ve ardalanın aktarılmadığı gözlenmiştir. Cumhurbaşkanı Erdoğan'ın ifadeleri üzerine inşa edilen haberde, Erdoğan'ın Macron'a yönelik ifadelerinin tamamına yer verilmeyerek bazı tanımlamaları bağlamından kopartılarak aktarılmıştır. Haberin tematik çözümlemesine göre, Fransa Cumhurbaşkanı Macron'un İslam'ı hedef alan söylemlerinin aklı başında bir kişinin söyleyebileceği ifadeler olmadığı ve bu bağlamda Macron'un "zihinsel tedaviye ihtiyacı" olan bir insan olduğu tanımlamasının ön plana çıkarıldığı gözlenmiştir. Haberde tercih edilen ilk görselde, manşetin hemen yanında Cumhurbaşkanı Erdoğan'ın fotoğrafına yer verilirken, ikinci görselde ise haber metninin yanında Fransa Cumhurbaşkanı Macron'un fotoğrafı kullanılmıştır. Haberde, Cumhurbaşkanı Erdoğan'ın ve Fransa Cumhurbaşkanı Macron'ın fotoğrafları ile haber içeriğinin bütüncül bir yapıda inşa edildiği ve bu bağlamda birbirilerini retoriksel açıdan desteklediği gözlenmiştir. Haberin mikro analizine göre, İslam'ı hedef alan Fransa Cumhurbaşkanı Macron söylemlerinden dolayı "zihinsel tedaviye" ihtiyacı olan bir birey olarak tanımlanmıştır. Bu bağlamda haberin manşetinde "Macron'un tedaviye ihtiyacı var" ifadesinin, haberin içeriğinde "zihinsel bir tedaviye ihtiyacı var" şeklinde netleştiği dikkat çekicidir. Haberin söylemsel çerçevesinde Fransa Cumhurbaşkanı Macron'u hedef alan ifade biçimleri kullanılmış olmakla birlikte Emmanuel Macron, "Macron denilen zat", "Inanç hürriyetinden anlamayan, ülkesindeki milyonlarca farklı inanç mensubuna bu şekilde davranan bir devlet başkanı" gibi yorum içeren abartılı ifadeler tanımlanmıştır. Gazetenin bu tanımlamaları Cumhurbaşkanı Erdoğan'ın açıklamalarını doğrudan aktararak yaptığı görülmüştür. Bu bağlamda gazetenin tercih ettiği ifadelerle nesnel bir bakış açısına sahip olmadığı gözlenmiştir.

27 Ekim tarihli Hürriyet gazetesi gelișmeleri, "Girdiğiniz Yolun Sonu Felaket" manşeti altında büyük puntolarda aktarmıştır. Tematik olarak "Boykot Çağrısı Yaptı”, 
“Irkçılık Kışkırtılıyor” ara başlıklarının kullanıldığı haberde, haber kaynağı olarak Cumhurbaşkanı Recep Tayyip Erdoğan'ın ifadeleri tırnak işareti kullanılarak aktarılmıştır. Manşetin altında yer alan “Erdoğan'a CHP'den Destek” başlıklı haberde, CHP Parti Sözcüsü Faik Öztrak'ın Cumhurbaşkanı Recep Tayyip Erdoğan'ın boykot çağrısını desteklediği bilgisine yer verilerek Erdoğan'ın boykot çağrısına farklı siyasi çevrelerin de olumlu karşıladığına yönelik bir anlamın inşa edildiği görülmüştür. “ibrahim Kalın: İslamofobi Yükseliyor” başlıklı bir diğer haberde ise Cumhurbaşkanlığı Sözcüsü İbrahim Kalın'ın Avrupa'da İslamofobinin yükselmesine yönelik açıklaması üzerinden konuya dair değerlendirmede bulunulmuştur. Haberin mikro analizi sonrasında İslam dinine yönelik açıklamalarda bulunan Fransa Cumhurbaşkanı Macron'un ve Almanya'da yapılan cami saldırısına sessiz kaldığı belirtilen Almanya Başbakanı Merkel'in, İslam dinine yönelik tavırlarının "felaket" olarak tanımlandığı gözlenmiştir. Gazete, haberin manşetinde ön plana çıkardığı "felaket" tanımlamasını, haberin spotunda ve içeriğinde tekrarlayarak bütüncül bir söylemsel çerçeve inşa etmiştir. Aynı zamanda gazetenin İslamofobinin artmasında "ırkçıların ve faşist grupların" etkisinin olduğunu vurguladığı ve bu bağlamda Almanya Başbakanı Merkel'i ve Merkel'in tavrını benimseyenleri "faşist" olarak nitelendirdiği görülmüştür. Gazete, tercih ettiği bu ifade biçimlerini Cumhurbaşkanı Erdoğan'ın açıklamalarını doğrudan aktararak yapmıştır. Bu bağlamda gazete, olayı aktarırken nesnel bir bakış açısına sahip değildir ve tek bir kişinin anlatısını ön plana çıkararak haberin söylemsel çerçevesini inşa etmiştir.

28 Ekim tarihli Hürriyet gazetesinde, "Macron Siyasi Şizofren” ve "4 Partiden Macron Tezkeresi” başlıklı iki küçük habere yer verilmiştir. Tematik olarak spot ve ara başlıkların kullanılmadı̆̆ı "Macron Siyasi Şizofren” başlıklı haberde, Milliyetçi Hareket Partisi Lideri Devlet Bahçeli'nin Fransa Cumhurbaşkanı Emmanuel Macron'u hedef alan ifadelerine yer verilmiştir. Haberde Bahçeli'nin ifadeleri tırnak işareti ile aktarılırken, Bahçeli'nin Fransa Cumhurbaşkanı Macron'u “Cehaletin ve husumetin taşeronluğuna soyunmuştur", "müflis Macron”, "siyasi şizofren” ifadeleri ile tanımladığı görülmüştür. Gazete, haber kaynağı olarak Devlet Bahçeli'nin ifadelerini kullanmıştır ve bu ifadeler üzerinden Macron'a yönelik durum tanımlamasında bulunmuştur. Ayrıca habere konu olan Devlet Bahçeli'nin ifadelerinin bağlamından kopartılarak belirli ifadelerinin okuyucuya aktarıldığı, Bahçeli'nin ifadelerinin ardalanına dair bir açıklamaya yer verilmediği gözlenmiştir. "4 Partiden Macron Tezkeresi” başlıklı diğer haberde ise Macron'un İslam karşıtı açıklamalarını kınayan tezkerenin AKP, MHP, CHP ve iYi Parti'nin oylarılla geçtiği ifade edilmiştir. Haberlerin mikro analizine göre, gazetenin MHP lideri Devlet Bahçeli'nin ifadelerini doğrudan aktardığı görülmüştür. Gazetenin Bahçeli'nin ifadeleri üzerinden Macron'u "siyasi şizofren" olarak tanımladığı gözlenmiştir. Haberin içeriğinde tercih edilen “cehaletin ve husumetin taşeronluğuna soyunmuştur”, “... müflis Macron'un haddi değildir” ve "bu siyasi şizofren” gibi ifadeler ile bu düşünsel çerçevenin birbirini tamamlayacak şekilde inşa edildiği görülmüştür. Kısa cümlelerin kullanıldığı haberde, Fransa Cumhurbaşkanı Macron'u olumsuz bir şekilde niteleyen ifadeler ile Macron'u hedef alan bir anlatı yapısı ön plana çıkarılmıştır.

29 Ekim tarihli Hürriyet gazetesinde gelişmeler, "Müptezel Charlie” başlı̆ı̆ altında büyük puntolarda ve manşetin altında yer alan bir haber ile okuyuculara aktarılmıştır. Haberde tematik olarak spot kullanılmış olup, Hz. Muhammed'e ve Cumhurbaşkanı Erdoğan'a hakaret eden Charlie Hebdo dergisine tepki yağdığı belirtilmiştir. Gazetenin, haberin manşetinde Charlie Hebdo dergisini "müptezel” olarak tanımladığı, spotunda ise “Hazreti Muhammed'e ve Cumhurbaşkanı Erdoğan'a hakaret eden Fransız mizah dergisi" olarak betimlediği görülmüştür. Tematik olarak “Erdoğan: Namussuzlar” ara başlığının kullanıldığı haberde, Cumhurbaşkanı Recep Tayyip Erdoğan'ın Charlie Hebdo dergisinde Hz. Muhammed'i hedef alan ka- 
rikatüre yönelik tepkisine yer verilmiştir. Haber kaynağı olarak Cumhurbaşkanı Recep Tayyip Erdoğan'ın ifadeleri kullanılmıştır ve gazetenin haberin içeriğinde Erdoğan'ın açıklamalarını tırnak işareti kullanarak tarafsız bir bakış açısıyla aktarmaya çalıştığı görülürken, ara başlıkta ise Erdoğan'ın ifadelerini doğrudan başlığa taşıyarak tarafsızlığını kaybettiği belirlenmiştir. Gazetenin, habere konu olan olayın ardalanı hakkında detaylı bir bilgilendirmede bulunmadığı, haberin spotunda yüzeysel yapılan bir bilgilendirme ile yetindiği gözlenmiştir. Aynı zamanda gazetenin, konuya dair durum tanımlamasını Cumhurbaşkanı Erdoğan'ın ifadeleri üzerinden nesnel bir bakış açısıyla yapmaya çaııștığı görülürken, Erdoğan'ın açıklamalarının tamamına yer vermediği, bağlamından kopartarak aktardığı ve bu bağlamda nesnelliğini kaybettiği ön plandadır. Haberde görsel olarak Cumhurbaşkanı Erdoğan'ın fotoğrafına yer verilerek, haberin içeriğinin retoriksel açıdan desteklenmeye çalışıldığı tespit edilmiştir. Ancak fotoğraf üstü yazıda gündemde yer alan başka bir konuya dair bilgi aktarılmış olup, haber ve fotoğraf üstü yazı arasında anlamsal bir bütünlüğün sağlanmadığı gözlenmiştir. Haberin altında "Iğrençliğe Her Partiden Tepki” başlığı ile aktarılan bir diğer haberde ise Charli Hebdo dergisinde $\mathrm{Hz}$. Muhammed'i hedef alan karikatüre yönelik tepkilerini dile getiren farklı partilerden milletvekillerinin ifadelerine yer verilmiştir. Haberde dikkat çeken nokta ise gazetenin milletvekillerinin sözlerini tırnak işareti kullanmadan doğrudan aktararak bir anlamda milletvekillerinin söylemlerini içselleştiren ve olumlayan bir bakış açısıyla konuya dair yaklaşımını yansıtmasıdır. Bu anlamda gazetenin milletvekillerinin "bu zihniyet tiksinti verici bir noktada", "Charli Hebdo ahlaksızlık ve küfürbazlıkla insanla hayvanı ayıran sınırları çoktan aşmıştır” gibi ifadeleri üzerinden konuya dair bakış açısını ortaya koyduğu bulgulanmıştır. Haberin mikro analizine göre, gazetenin abartılı ifadeler ile yaşanan gelişmeleri aktardığı gözlenmiștir. Haberde kısa cümleler tercih edilmiş olmakla birlikte edilgen ve aktarım fiillerinin hâkim olduğu bir anlatı yapısı inşa edilmiştir. Gazete, Charlie Hebdo dergisini Cumhurbaşkanı Erdoğan'ın açıklamaları üzerinden "müptezeller”, "namussuzlar” olarak tanımlamayı tercih etmiştir. Aynı gün yer alan bir diğer haberde ise Charlie Hebdo dergisinin Hz. Muhammed'i hedef alan karikatürleri "iğrençlik" olarak nitelendirilmiştir. Bu karikatürlere tepki veren kişilerin “... bu zihniyet tiksinti verici bir noktada”, “... yayınlanan karikatürler edepsizliktir, aşağılık ötesidir” gibi ifadeleri üzerinden bütüncül bir söylemsel oluşturulmaya çalışılmıştır.

Hürriyet gazetesi, 30 Ekim tarihli sayısında manşetin altında "Fransa'da Deaş Kafası Hortladı" başlıklı küçük bir haber ile gelişmeleri aktarmıştır. Başlığın büyük harfler ile dikkat çekici hale getirildiği haberde tematik olarak spot kullanılmış olup, Fransa'nın Nice kentinde bir kilisede terör saldırısının meydana geldiği ifade edilmiştir. Haberin spotunda Fransa, "Islam inancına karşı sert söylemlerin gündemde olduğu” bir ülke olarak betimlenirken, gazetenin yaşanan saldırıyı "vahşi bir terör saldırısı"olarak tanımladığı ve bu bağlamda manşette saldırıyı "Deaş Kafası Hortladı” şeklinde ifade ettiği görülmüştür. Haberin içeriğinde saldırıyı gerçekleştiren kişi terörist olarak tanımlanmıştır ve bu bağlamda gazete haberin manşeti, spotu ve içeriği arasında bütüncül bir söylemsel çerçeveyi inşa etmiştir. Tematik olarak “3 Kişiyi Bıçakla Öldürdü” ara başıı̆̆ının kullanıldığı haberin içeriğinde ise saldırıyı özetleyen bilgilere yer verilmekle birlikte saldırının esas gerekçelerinin açıklanmadığı gözlenmiştir. Haberde tercih edilen görsellerin ilkinde Fransa Cumhurbaşkanı Macron'un fotoğrafına yer verilirken, ikincisinde ise bir binanın önünde kalabalık polis gruplarının olduğu bir fotoğraf tercih edilmiştir. Haberde tercih edilen görsellere dair kullanılan kaynaklar belirtilmemiş olup, aynı zamanda görsellerin haberin içeriğini retoriksel açıdan destekleyici bir şekilde kullanılmadığı görülmüştür. Haberin mikro analizine göre, haberde kısa yapılı cümleler ile abartılı ifade biçimlerinin ön planda olduğu görülmüştür. Gazetenin Fransa'da yaşanan saldırıyı "Deaş kafası hortladı", "vahşi bir terör saldırısı" gibi abartılı ifadeler temelinde aktarmayı seçtiği ve "kınadı", “öldürdü”, "katletti” gibi etken yapılı fiiller ile anlatmayı tercih ettiği gözlenmiştir. Aynı zamanda gazete, Fransa'da İslam dinine karşı yükselen ifade biçimlerini "sert söylemler" olarak tanımlamıştır. 


\section{Sabah Gazetesi}

Sabah gazetesi 25 Ekim tarihli sayısında, "Avrupa Faşizmi Yeni Bir Safhaya Geçti” başlığı altında büyük harfler ile gelișmeleri aktarmıştır. Haberde tematik olarak spot kullanılmış olup, haberin konusunu özetleyen açıklayıcı bilgilere yer verilmemiştir. Spotta, Cumhurbaşkanı Recep Tayyip Erdoğan'ın “Bu tehlikeli gidiş, insanlık tarihinin en büyük katliamlarını gerçekleştiren Avrupa'nın hala aklının başına gelmediğini gösteriyor" açıklaması tırnak işareti kullanılmadan doğrudan aktarılmıştır. Tematik yapı incelemesine göre gazetenin Cumhurbaşkanı Recep Tayyip Erdoğan'ın ifadelerini haber kaynağı olarak kullandığı ve haberin söylemsel çerçevesini bu temelde inşa ettiği görülmüştür. Avrupa'da artan İslam karşıtlığına dair durum tanımlamasını Cumhurbaşkanı Erdoğan'ın açıklamaları üzerinden yapan gazetenin, aynı zamanda konuyu bağlamından kopartarak Erdoğan'ın açıklamaları temelinde ve tek bir kişinin konuya yönelik değerlendirmesi üzerinden ele aldığı gözlenmiştir. Bu bağlamda gazetenin söz konusu durumu aktarırken nesnel bir bakış açısına sahip olmadığı, Cumhurbaşkanı Erdoğan'ın ifadeleri üzerinden konuya dair bakış açısını taraflı bir şekilde ortaya koyduğu belirlenmiştir. Haberin tematik çözümlemesine göre haberde öne çıkan ana temanın, Avrupa'da İslam dinine karşı "cephe" açıldığının ve bu durumun İslam karşıtlığı temelinde şekillendiğinin, başrolünde ise Fransa Cumhurbaşkanı Macron'un yer aldığı düşüncesinin olduğu gözlenmiştir. Haberde kullanılan ilk görselde Cumhurbaşkanı Erdoğan'ın fotoğrafına yer verilirken, ikinci görselde ise havuzlu bir sitenin fotoğrafı kullanılmıştır. Görsellerin üstünde yer alan yazılarda ise Erdoğan'ın Kayseri'de AKP IIl Kongresi'ne ve Kentsel Dönüşüm Anahtar Teslim Töreni'ne katıldığı bilgileri aktarılmıştır. Bu doğrultuda haberin içeriği ile haberde tercih edilen görsellerin ve yazılarının retoriksel açıdan birbiri ile uyumlu şekilde kullanılmadığı görülmüştür. Haberin mikro analizine göre, haberin söylemsel çerçevesinin basit cümleler ile hikâye tarzında oluşturulduğu ve bu söylemsel çerçevenin Cumhurbaşkanı Erdoğan'ın ifadelerinin tırnak işareti kullanılmadan aktarılması ile inşa edildiği gözlenmiştir. Bu temelde Avrupa ülkelerinde yükselen İslam ve Müslüman düșmanlığı, Erdoğan'ın açıklamaları üzerinden "Avrupa Faşizmi” olarak tanımlanmıştır. Haberinde manşetinde yapılan bu tanımlamanın haberin içeriğinde ise "bu tehlikeli gidiş", "en büyük katliamları gerçekleştiren Avrupa”, “Avrupa Müslümanlara karşı açtığı cepheyle kendi sonunu hazırlıyor” gibi ifadelerin kullanımı ile desteklendiği dikkat çekicidir. Bu bağlamda gazetenin tercih ettiği kelime ve kelime grupları ile bütüncül bir söylemsel çerçeve inşa ettiği gözlenmiştir. Gazetenin bu tanımlamaların yanı sıra Fransa Cumhurbaşkanı Macron'u hedef alan ifade biçimlerini de tercih ettiği görülmüştür. Bu bağlamda gazetenin Cumhurbaşkanı Erdoğan'ın ifadeleri üzerinden Macron'u "zat" ve "zihinsel tedaviye ihtiyacı" olan bir insan olarak tanımladığı sonucuna varıımıştır.

Gazetenin 26 Ekim tarihli sayısında yer alan "Oyunlarını Bozduk Bizi Hedefe Koydular” manşetli haberinde, Cumhurbaşkanı Recep Tayyip Erdoğan'ın Adalet ve Kalkınma Partisi'nin Malatya il Kongresi'nde yaptığı konuşmasında Emmanuel Macron'a yönelik ifadelerine yer verilmiştir. Gazete, haberin içeriğinde bir iki cümle şeklinde Erdoğan'ın Emmanuel Macron'a yönelik ifadelerini tırnak işareti kullanmadan aktarmayı tercih etmiştir. Bu bağlamda gazetenin Erdoğan'ın “FRANSA'NIN başındaki zat (Macron). Yatıyor, kalkıyor Erdoğan... Önce kendine bak. Bu bir vaka. Bir kontrolden geçmesi lazım." ifadelerini içselleştirerek aktardığı ve bu ifadeler üzerinden Fransa Cumhurbaşkanı Macron'a yönelik tarafsız bir bakış açısına sahip olmadığı tespit edilmiştir. Cumhurbaşkanı Erdoğan'ın ifadelerini bağlamından kopartarak aktaran gazetenin, habere konu olan olayın geri planı hakkında da bir bilgilendirme yapmadığı gözlenmiştir. Bir iki cümleden oluşan haberin mikro analizine bakıldığında ise bir önceki gün Fransa Cumhurbaşkanı Macron'a yöneltilen "zat" tanımlamasının bu haberde devam ettirildiği bulgulanmıştır. 
Gazetenin 27 Ekim tarihli sayısında gelişmeler, "Fransız Mallarını Sakın Almayın” manşeti altında büyük puntolarda verilmiştir. Haberde tematik olarak spot kullanılmış olup, Cumhurbaşkanı Erdoğan'ın “Başkan Erdoğan: Milletime sesleniyorum; nasıl ki Fransa'da "Türk markalı ürünleri almayın" deniyorsa, siz de Fransız markaları asla satın almayın" sözleri ağızdan verilmiştir. Tematik yapı incelemesine göre haberde, Erdoğan'ın ifadeleri haber kaynağı olarak kullanılmıştır ve haberin söylemsel çerçevesi Erdoğan'ın Avrupa ülkelerinde artışa geçen İslam karşıtlı̆̆ına yönelik değerlendirmeleri üzerinden inşa edilmiştir. Haberin genel söylemsel çerçevesi Erdoğan'ın söz konusu olaya yönelik durum tanımlaması ile inşa edilmiştir ve haberin manşetinde, spotunda Fransa'ya karşı öne çıkan vurgunun, haberin içeriğinde genel olarak devam ettirildiği görülmüştür. Tematik olarak "Macron Teșvik Ediyor”, "Siz Gerçek Faşistsiniz" ara başlıklarının kullanıldığı haberin içeriğinde, Avrupa ülkelerinde İslam ve Müslüman karşıtlığının arttığı, özellikle Fransa'daki artışın temelinde ise Fransa Cumhurbaşkanı Macron'un söylemlerinin etkisinin olduğuna dair vurgunun ön plana çıkarıldığı gözlenmiştir. Haberin tamamında Erdoğan'ın ifadelerinin tırnak işareti kullanılmadan aktarıldığı ve bu anlamda gazetenin Erdoğan'ın söylemlerini içselleştirdiği, konuyu ele alırken tarafsız bir bakış açısına sahip olmadığı görülmüştür. Ardalan ve bağlam bilgisinin bulunmadığı haberde tercih edilen ilk görsele bakıldığında ise Erdoğan'ın fotoğrafına yer verilmiş olup, fotoğraf üstü yazıda haberin içeriğinden farklı bir konu dile getirilmiştir. "Islam Dünyasından Macron'a Öfke" ifadesi ile verilen görselde ise ellerinde İngilizce "Terrorist The World Biggest Terrorist France” ifadelerinin yazılı olduğu ve Macron'un yüzünde ayak izi olan pankart tutan bir grubun fotoğrafına yer verilmiștir. Fotoğraf üstü yazıda İslam ülkelerinde Fransız ürünlerine boykotun yaygınlaştığı ifade edilmiştir. Ancak aktarılan ifadelerin ve görselin kaynağı belirtilmemiştir. Haberin mikro analizine göre, gazete haberin içeriğinde emir ve tanım bildiren cümle yapılarına ağırlık vermiştir. Gazete, Cumhurbaşkanı Erdoğan'ın ifadeleri üzerinden haberin söylemsel çerçevesini inşa etmiştir ve bu ifadeleri doğrudan aktararak içselleştirmeyi tercih etmiştir. Haberin söylemsel çerçevesinin "Fransız mallarını sakın almayın" çağrısı temelinde inşa edildiği ve bu bağlamda haberin manşetinde, spotunda ve içeriğinde bu ifadenin tekrarlanması ile birbirini destekleyen bir anlatının oluşturulduğu gözlenmiştir. Aynı zamanda gazetenin Fransa Cumhurbaşkanı Macron'u “Fransa'nın akli kontrole muhtaç olan lideri”, Almanya Başbakanı Merkel'i ise "işte siz gerçek manada gerçek faşistsiniz, siz gerçek manada Nazi'nin zincir halkalarından birisiniz" şeklinde abartılı ifadeler tanımlayan bir üslubu benimsediği görülmüştür. Bu bağlamda gazetenin söz konusu olayı aktarırken nesnelliğini kaybettiği ve taraflı bir bakış açısıyla olayı değerlendirdiği gözlenmiştir.

28 Ekim tarihli Sabah gazetesinde gelişmeler, “Küstah Macron’a Tepkiler Çığ Gibi” başlığı altında büyük puntolarda verilmiștir. Haberin spotunda, Fransa Cumhurbaşkanı Emmanuel Macron'un İslam'a yönelik açıklamalarının "skandal” olarak tanımlandığı ve ifadelerinin dünyanın farklı yerlerinde protesto edildiği belirtilmiştir. Haberin girişinde, Macron'un "haddini aşan" ifadesi ile tanımlandığı ve sözlerine yönelik tepkilerin devam ettiği belirtilerek haberin manşetinde ve spotunda öne çıkan söylemsel çerçevenin haberin devamında sürdürüldüğü görülmüştür. Haberde söz konusu olayın ardalanına yer verilmediği ve haber kaynaklarının belirtilmediği gözlenmiştir. Haber için tercih edilen görsellerin ilkinde ellerinde bayraklar olan kalabalık bir grubun fotoğrafı yer alırken, ikinci görselde Macron'un posterinin yanarken çekilmiş bir fotoğrafı verilmiş olup üçüncü görselde ise bir grubun ellerinde "küstahlığı protesto ediyoruz" ifadelerinin ve Macron'un yüzünde ayak izinin olduğu bir pankart taşıyan grubun açıklama yaparken çekilmiş fotoğrafı kullanılmıştır. Haberde kullanılan görseller, retoriksel açıdan haberin söylemsel çerçevesini desteklemektedir ancak fotoğrafların kaynağının belirtilmediği dikkat çekmektedir. Gazetenin 28 Ekim tarihinde aktardığı haberin mikro analizi sonrasında kısa ve anlaşılır cümlelerin tercih edildiği görülmüştür. Haberin içeriğinde "protesto edildi", "gösteri düzenledi”, "boykot çağrısı yapıldı" gibi et- 
ken yapılı fiillerin kullanıldığı gözlenmiştir. Haberin manşetinde ön plana çıkartılan “Küstah Macron'a tepkiler çığ gibi” ifadesinin haberin içeriğinde de "Haddini aşan Fransa Cumhurbaşkanı Macron" şeklinde devam ettirilerek birbirini tamamlayacak şekilde kullanıldığı görülmüştür. Aynı zamanda Macron'a yönelik tepkilerin çığ gibi büyüdüğüne yönelik belirginleşen ifadenin, haberin içeriğinde farklı şekillerde vurgulanarak ön plana çıkarıldığı gözlenmiştir.

Gazetenin 30 Ekim tarihli sayısında gelişmeler, “Fransız Paçavrasına BM'den de Sert Tepki” başlıkı küçük bir haber ile verilmiştir. Haberin spotunda, Charlie Hebdo dergisinde yayınlanan "aşağılık bir karikatür" olduğu bilgisine yer verilmekle birlikte karikatürün içeriğine ve neden "aşağılık" olduğuna dair bir açıklayıcı bir ifade yoktur. Gazetenin haberin manşetinde "Fransız Paçavrası" olarak tanımladığı şeyin, spotta "Charlie Hebdo" dergisi olduğu anlaşılmaktadır ve manşettekine benzer şekilde derginin "provokatör" olarak tanımlandığı, dergide yer alan karikatürün ise "aşağılık" olarak ifade edildiği gözlenmektedir. Haberin içeriğinde BM Yüksek Temsilcisi'nin Charlie Hebdo dergisinde Hz. Muhammed'i hedef alan karikatürleri olumsuzlayan ifadelerine yer verilirken, gazetenin BM Yüksek Temsilcisi'nin ifadelerini tırnak işareti kullanmadan doğrudan aktararak içselleştirdiği görülmektedir. Bu bağlamda gazetenin konuya dair tarafsız bir bakış açısına sahip olmadığı, BM Yüksek Temsilcisi'nin konuya dair değerlendirmeleri üzerinden durum tanımlamasında bulunduğu dikkat çekmektedir. Ardalan bilgisinin bulunmadı̆̆ı haberde, aynı zamanda BM Yüksek Temsilcisi'nin ifadelerinin bir bölümüne yer verilerek bağlamından kopartılarak belirli bir çerçevede aktarıldığı görülmektedir. Haberde kullanılan görsele bakıldığında ise Macron'un fotoğrafının hayvan gövdesine yerleştirilmiş pankartını tutan insanlara ait bir fotoğraf tercih edilmiştir. Ancak haberde kullanılan görsel ile haberin içeriğinin birbirini destekleyen nitelikte olmadığı, tercih edilen görselin kaynağına dair bir bilgiye de yer verilmediği dikkati çekmektedir. 30 Ekim tarihinde yer alan haberin sentaktik analizine göre abartılı bir anlatımın tercih edildiği belirlenmiştir. Gazetenin, haberin manşetinde Charlie Hebdo dergisini “Fransız Paçavrası" olarak tanımladığı ve bu söylemini destekleyecek ifadeleri haberin içeriğinde kullandığı gözlenmiştir. Bu bağlamda gazetenin "Provokatör dergi Charlie Hebdo" ifadesi ve dergide yayınlanan karikatürlerin "aşağılık" olarak tanımlanması ile bütüncül bir söylem inşa etmeye çalıştığı sonucuna varılmıştır.

\section{Sözcü Gazetesi}

Sözcü gazetesi 25 Ekim tarihli sayısında yaşanan gelişmeleri, "Erdoğan, Fransa Cumhurbaşkanı'na Böyle Çıkıştı:” üst başlığı ve "Macron'un Zihinsel Tedaviye îhtiyacı Var" başlığı ile manşetin altında yer alan bir haber ile aktarmıştır. Üst başlık ve başlıktan Cumhurbaşkanı Recep Tayyip Erdoğan'ın ifadeleri üzerinden inşa edildiği görülen haberde tematik olarak spot kullanılmış olup, Erdoğan'ın Macron'a yönelik açıklamalarından sonra Fransa'nın Türkiye büyükelçisini istişare için geri çağırdığı ifade edilmiştir. Haberin üst başlığı, başlığı ve spotunda öne çıkan söylemsel çerçeveye bakıldığında gazetenin, Erdoğan'ın Macron'a yönelik neden açıklamada bulunduğuna dair konuyu özetleyen herhangi bir bilgiye yer vermediği görülmüştür. Ara başlığın kullanılmadığı haberde, haber kaynağı olarak Erdoğan'ın ifadeleri temel alınmıştır. Haberin devamında Erdoğan'ın, “Türkiye karşı söylemlerde bulunan ve İslamiyet'e dil uzatan Fransa Cumhurbaşkanı Macron'a yüklendiği”" belirtilmiştir. Bu bağlamda haberde ön plana çıkan anlama bakıldığında gazetenin Cumhurbaşkanı Erdoğan'ın, Fransa Cumhurbaşkanı Macron'a yönelik açıklamalarını "çıkışmak" ve "yüklenmek" olarak tanımladığı ve bu doğrultuda Erdoğan'ın ifadelerini olumsuz bir temelde yansıttığı gözlenmiştir. Bu çerçevede gazetenin, Erdoğan'ın açıklamalarını bağlamından koparttığı ve konuya dair durum tanımlamasını bağlamından kopartılmış ifadeler üzerinden yaptığı ve bu anlamda gaze- 
tenin konuyu tarafsız bir bakış açısıyla ele almadığı belirlenmiștir. Haber retoriğinin, Cumhurbaşkanı Erdoğan'ın küçük bir fotoğrafı ile desteklenmeye çalışıldığı bulgulanmıştır. Haberin mikro analizine göre haberde, kısa ve anlaşılır cümlelerin tercih edildiği gözlenmiştir. Gazetenin haberin genel söylemsel çerçevesinde Fransa ile yaşananların sorumlusu olarak Cumhurbaşkanı Erdoğan'ı ön plana çıkardığı dikkati çekmektedir. Bu bağlamda gazetenin haberin üst başlığında "Erdoğan, Fransa Cumhurbaşkanı'na böyle çıkıştı” ifadesini, haberin spotunda “Erdoğan'ın Macron'a yönelik sözlerinin ardından” ifadesi, haberin içeriğinde ise "Erdoğan... Emmanuel Macron'a yüklendi” ifadesi ile desteklediği ve bu bağlamda haberin genelinde bütüncül bir söylemsel çerçeve inşa ettiği gözlenmiştir. Haberde kullanılan cümlelerin yapılarına bakıldığında ise "yüklendi", "dedi”, “çıkıştı” gibi etken yapılı cümlelerin tercih edildiği görülmüştür.

27 Ekim tarihli Sözcü gazetesinde gelişmeler, "Köşeye Sıkışınca iftiraya Sarıldı" üst başlığı ve "Yalancı Macron" başlığı ile sayfanın en altında küçük bir haber ile verilmiştir. Haberde tematik olarak spot ve ara başlık kullanılmamış olup, haberin içeriğinde Fransa Cumhurbaşkanı Macron'un Türkiye'nin Fransa'da kafası kesilerek öldürülen öğretmen için başsağlığı mesajı yayınlamadığını ileri sürdüğü ifade edilmekle birlikte Fransız basınının bu durumu yalanladığı belirtilmiştir. Haberin üst başığı, başlığı ve haberin içeriğine bakıldığında Fransa Cumhurbaşkanı Macron'un “yalancı" olduğuna dair bütüncül bir söylemsel çerçevenin inşa edildiği görülmüștür. Ancak Macron'u “köşeye sıkıştıran" şeyin ne olduğunun belirtilmediği ve bu anlamda söz konusu durumun ardalanı hakkında bilgilendirmenin yapılmadığı gözlenmiştir. Haberde yer alan "Yalancı Macron" başığının, ifadenin yanında yer alan Macron'un görseli ile retoriksel olarak desteklendiği ve ifadenin altındaki fotoğrafı işaret eden ok işareti ile daha da güçlendirildiği görülmüştür. Haberin mikro analizine göre haberde, kısa ve anlaşılır ifade biçimlerinin kullanıldığı gözlenmiştir. Haberin manşetinde Macron’a yönelik yapılan “yalancl" tanımlamasının, haberin içeriğinde aktarılan bilgiler doğrultusunda teyit edilmeye çalışıldığı ön plandadır. Bu bağlamda gazetenin haberin içeriğinde bütüncül bir söylem inşa etmeye çalıştığı belirlenmiştir.

Gazetenin 28 Ekim tarihli sayısında gelişmeler, “Merkel, Macron'un Yanında Saf Tuttu” başlığı ve tek cümlelik “Almanya Başbakanı, Erdoğan'ın Macron’a yönelik eleştirilerini, "kesinlikle kabul edilemez" bulduğunu açıkladı." ifadesi ile aktarılmıştır. 30 Ekim tarihli Sözcü’de, “Nice'ta Kafa Kestiler” başlığı altında verilen küçük bir haber ile gelişmeler aktarılmıştır. Sayfanın altında kırmızı arka fon ile dikkat çekici hale getirilen haber, “Nice'ta Kafa Kestiler” başlığı ve “Fransa 2. Dehşeti Yaşadı” ifadesiyle verilmiştir. Tematik olarak spot ve ara başılıların kullanılmadığı haberin içeriğinde, "islam karşıtı söylemleriyle nefret toplayan Fransa'da terör... Nice'te kiliseye giren saldırgan, 2 kişiyi kafasını keserek, 1 kişiyi ise bıçaklayarak öldürdü. Saldırgan yaralı yakalandı. Türkiye saldırıyı kınadı..." ifadeleri yer almıştır. Gazetenin Fransa'yı “islam karşıtı söylemleriyle nefret toplayan" ülke olarak tanımladığı, gerçekleştirilen saldırıyı ilk başta "terör" olarak tanımlarken daha sonra "saldırı" olarak ifade ettiği ve saldırıyı gerçekleștireni "saldırgan" olarak belirttiği görülmüştür. Bu bağlamda gazetenin gerçekleştirilen saldırıyı tanımlama noktasında net bir bakış açısına sahip olmadığı, konuyu ardalanı ve bağlamı olmaksızın ele aldığı gözlenmiştir. Haberin, bir bina önünde kalabalık grupların olduğu bir görsel ve "Notre-Dame Kilisesi kana bulandı" ifadesi ile verildiği dikkat çekmektedir. Ancak verilen görselde haber kaynağının kullanılmamış olması, haberde yer verilen görselin konuya ait olup olmadığı noktasında belirsizliğe yol açtığı gözlenmiştir. Haberin mikro analizine göre haberde, abartılı ifade biçimleri ile haberin söylemsel çerçevesinin inşa edildiği ön plandadır. Bu bağlamda haberde kullanılan "kafa kestiler", "dehşeti yaşadı", "kana bulandı" gibi ifadeler ile bütüncül bir söylem inşa edilmiştir. Haberde etken ve edilgen yapılı cümleler kullanılmış olup, saldırıyı betimleyici ifadeler kullanılmıştır. Aynı zamanda Fransa'nın “islam karşıtı söylemleriyle nefret toplayan” ülke olarak tanımlandığı gözlenmiştir. 


\section{Yeni Şafak Gazetesi}

Yeni Şafak gazetesi 25 Ekim tarihli sayısında yaşanan gelişmeleri, "Macron'un Tedaviye ihtiyacı Var" ifadesi ile kırmızı renkli büyük puntolarda sürmanşetten okuyuculara aktarmıştır. Tematik olarak spot ve ara başlıkların kullanılmadığı haberin içeriğinde, Cumhurbaşkanı Recep Tayyip Erdoğan'ın Fransa Cumhurbaşkanı Macron'a dair ifadelerine yer verilmiştir. Haber kaynağı olarak Cumhurbaşkanı Erdoğan'ın ifadeleri temel alınmıs olup, aktarılan konuya dair Erdoğan'ın değerlendirmeleri üzerinden haberin söylemsel çerçevesi inşa edilmiştir. Konuya dair ardalan bilgisine yer verilmediği haberin içeriğinde, Erdoğan'ın "Macron denilen zatın İslam ile Müslümanlarla derdi nedir? Macron'un zihinsel noktada bir tedaviye ihtiyacı var" ifadelerine yer verilmiştir. Ancak aktarılan ifadelerin bağlamından kopartılarak belirli bir çerçevede verildiği gözlenmiştir. Gazete, bu ifadeleri haberin içeriğinde tırnak işareti kullanarak aktarırken, haberin manşetinde ise doğrudan aktarmayı tercih etmiştir. Bu doğrultuda gazetenin konuyu nesnel bir bakış açısıyla ele aldığı izlenimini oluşturmaya çalıştığı, ancak tarafsız bir şekilde aktaramadığı görülmüștür. Gazetenin Erdoğan'ın ifadeleri üzerinden Macron'u "zihinsel tedaviye ihtiyaca gerek duyan" bir insan olarak gördüğü ve bunu da haberin söylemsel yapısında ön plana çıkardığı gözlenmiştir. Haberin mikro analizine göre haberin söylemsel çerçevesinin aktarım cümleleri ile inşa edildiği tespit edilmiştir. Bu bağlamda gazetenin Cumhurbaşkanı Erdoğan'ın ifadelerini doğrudan aktardığı ve bu ifadeleri temel alarak konuya dair bakış açısını ortaya koyduğu gözlenmiştir. Haberin içeriğinde kısa ve anlaşılır cümleler kullanılmış olmakla birlikte Fransa Cumhurbaşkanı Macron'u hedef alan ifade biçimleri tercih edilmiştir. Bu ifade biçimleri haberin manşetinde ve içeriğinde birbirini tamamlayan bir şekilde kullanılmıştır. Bu bağlamda gazetenin manşetinde yer alan "Macron'un tedaviye ihtiyacı var" ifadesinin, haberin içeriğinde de "zihinsel bir tedaviye ihtiyacı var" şeklinde aktarılarak ön plana çıkarıldığı belirlenmiştir.

26 Ekim tarihli Yeni Şafak gazetesi, "Oyunlarını Bozduk Hedef Olduk" sürmanşeti ile büyük puntolarda gelişmeleri aktarmıştır. Gazete Cumhurbaşkanı Erdoğan'ın ifadelerini spota taşımıştır. Spotta, Cumhurbaşkanı Erdoğan'ın ABD ve Avrupa'da yükseldiğini ifade ettiği Türk düşmanlığına dikkat çektiği belirtilmiştir ve bu konuya dair Erdoğan'ın sert açıklamalarına yer verilmiştir. Haberde tematik olarak "Macron Bir Vaka" ve "Wilders'a: Haddini Bil” ara başlıkları kullanılmıştır. Gazetenin ara başlıkta Erdoğan'ın ifadeleri üzerinden Macron'u "bir vaka" olarak tanımladığı görülürken, haberinde içeriğinde de “Fransa'nın başındaki zat şaşırmış, yatıyor kalkıyor Erdoğan'la uğraşıyor. Kayseri'de de söyledim bu bir vaka. Onun için hakikaten kontrolden geçmesi lazım" şeklinde ifade ettiği gözlenmiştir. Benzer şekilde Hollanda'da milletvekili olan Wilders'ın ise "Hollandalı ırkçı parti başkanı" ve "milletvekili müsveddesi" olarak tanımlandığı dikkati çekmektedir. Haberin manşetinde ve spotunda "hedef olan" ve "hedef tahtasına koyulan" kişinin net olarak Cumhurbaşkanı Erdoğan'ın olduğu ifade edilmezken, haberin içeriğinde bu durumun “Fransa'nın başındaki zat şaşırmış, yatıyor kalkıyor Erdoğan'la uğraşıyor..." ve "Bir de Hollanda'da bir milletvekili müsveddesi var. O da kalkmış bizimle ilgili yine bir şeyler yapıyor..." ifadeleri ile netlik kazandığı gözlenmiştir. Haberin tematik yapı incelemesine göre haberde kaynak olarak Cumhurbaşkanı Erdoğan'ın açıklamaları kullanılmıştır. Erdoğan'ın konuya dair değerlendirmeleri üzerinden haberin genel söylemsel çerçevesinin inşa edildiği ve gazetenin bu açıklamaları haberin manşetinde, ara başıklarında ve içeriğinde aktarırken tırnak işareti kullanmayarak içselleştirdiği bulgulanmıştır. Erdoğan'ın Macron'a ve Wilders'a yönelik açıklamalarda bulunmasının temel nedeni hakkında yeterli bir bilgilendirmenin yapılmadığı ve bu anlamda konunun ardalanının aktarılmadığı gözlenmiştir. Haberin ana temasında ise uluslararası arenada Cumhurbaşkanı Erdoğan ile uğraşıldığına dair bir 
düşüncenin ön plana çıkarıldığı ve bu duruma dair Erdoğan'ın ifadeleri üzerinden sert tepkilerin verildiği dikkat çekmektedir. Haberin mikro analizine göre haberde, uzun cümleler ve aktarım yapılı fiiller tercih edilmiştir. Gazete, Cumhurbaşkanı Erdoğan'ın açıklamaları üzerinden haberin söylemsel çerçevesini inşa etmiş, bu doğrultuda konuya dair bir bakış açısı ortaya koymuştur. Gazete haberin söylemsel çerçevesinde Avrupa'da ve Amerika'da Türk düşmanlığının arttığına yönelik bir anlatıyı ön plana çıkarmıştır. Bu bağlamda Erdoğan'ın ifadeleri üzerinden bu düşmanlığa vurgu yapılmıştır. Haberin içeriğinde Macron'un, Erdoğan'la uğraştığına vurgu yapılmakla birlikte Wilders'ın da aynı tavra sahip olduğu belirtilmiştir. Bu temelde Avrupa ülkelerinde artan Türk düşmanlığına yönelik söylemsel pratiklerin haberin içeriğinde aktarılan ifadeler ve cümleler ile desteklendiği görülmüştür. Ayrıca gazetenin Macron'u "bir vaka”, "Fransa'nın başındaki zat" ifadeleri ile tanımlarken, Wilders'ı da "bir milletvekili müsveddesi" olarak betimlediği gözlenmiştir.

Gazete 27 Ekim tarihli sayısında gelişmeleri, "Erdoğan'dan Boykot Çağrısı” üst başlığı ve "Fransız Malı Almayın" ifadesi ile büyük puntolarda manşetten vermiştir. Haberin spotunda Fransa'nın “Müslümanların sokakta, çarşıda, okulda, otobüste ve işyerlerinde saldırıya uğradığı Fransa bardağı taşırdı" şeklinde tanımlandığı ve Cumhurbaşkanı Erdoğan'ın Fransız ürünlerine karşı boykot çağrısında bulunduğu ifadelerine yer verildiği ve bu ifadeleri altı çizili bir şekilde aktararak vurguladığı görülmüştür. Tematik olarak "AP Üç Maymunu Oynuyor”, "Müslümanlar Şiddete İtiliyor”, "Polisler Camiyi Nasıl Basar” ve "Bu Yolun Sonu Felaket” ara başlıklarının kullanıldığı haberde, Cumhurbaşkanı Erdoğan haber kaynağı olarak kullanılmıştır. Haberin söylemsel çerçevesinin Erdoğan'ın açıklamaları üzerine kurulu olan haberde, Avrupa'da artan İslam düşmanlığına dair Erdoğan'ın ifadeleri tırnak işareti kullanılmadan aktarılmış olup, bu ifadeler üzerinden konuya dair bir değerlendirmenin ön plana çıkarıldığı görülmüştür. Bu bağlamda gazetenin tarafsız bir bakış açısına sahip olmadığı, konuyu nesnel bir şekilde ele almadığı, tek bir kişinin değerlendirmeleri üzerinden konuyu aktardığı gözlenmiştir. Ayrıca manşetin altında yer alan “Bu Boykot Fransa'yı Sarsar” başılıkı bir haber ile Fransa'nın boykot çağrıları ile karşı karşıya olduğu, bu boykotların karşıı bulması halinde ekonomik bir çöküş yaşama durumunun söz konusu olabileceği belirtilmiştir. Benzer şekilde "Fransa'da İç Karışıklık Çıkabilir” başlıklı bir diğer haberde ise bir uzmanın Fransa'da yaşayan Müslüman nüfusun bir bütün olarak tepki koyması halinde Fransa'da iç karışıklığa varan sonuçlar doğurabileceğine yönelik ifadelerine yer verilmiştir. Haberin retoriksel çerçevesini desteklemek için Cumhurbaşkanı Erdoğan'ın fotoğrafı kullanılmıştır. Haberin mikro analizine göre haberin genel söylemsel çerçevesinde hikâye tarzı bir anlatım biçiminin benimsendiği ve bu temelde cümle yapılarının tercih edildiği belirlenmiştir. Haberde, kısa ve anlaşılır cümlelerin yanı sıra abartılı bir anlatımında yer yer kullanıldığı gözlenmiştir. Haberin içeriğinde "bardağı taşırdı", "AP üç maymunu oynuyor" gibi ifadeler ile abartılı bir anlatım tercih edilmiştir. Haberin manşetinde ve spotunda "Fransız malı almayın" çağrısının vurgulanarak ön plana çıkarıldığı, haberin içeriğinde ise İslam dinine ve Müslümanlara yönelik düşmanlıkların varlığının dile getirilerek konuya dair bütüncül bir söylemin inşa edilmeye çalışıldığı görülmüştür. Haberde genel olarak "yaptı”, "söyledi” gibi etken yapılı fiiller ön plana çıkarılmıştır.

Gazete 28 Ekim tarihli sayısında gelişmeleri, “Boykotla Ders Verelim” ifadesi ile büyük puntolarda manşetten aktarmışırı. Haberde tematik olarak spot kullanılmış olup, “islam düşmanlığı ve nefretin Avrupa'daki merkezi” olarak tanımlanan Fransa'ya yönelik boykot çağrısının büyüdüğü ve boykot çağrısına uyulduğu sürece "Macron'un güç geçtikçe küstahlaşan faşizmine önemli bir ders verileceği” belirtilmiştir. Haberin tematik yapı incelemesine göre haberde"Güçlü Şekilde Olmalı", "Fransız Malı İstemeyelim”, “Ortak Bilinç Oluşmalı”, “Faşizme Dur Demek Olur”, “Üyelerimiz Duyarsız Kalmasın”, "Mesajımız Güçlü Olmalı” ara başlıkları kullanılmıştır. Haberin içeriğinde, 
Fransız ürünlerine boykotun nasıl olması gerektiğine dair farklı kurumlardan kişilerin ifadeleri aktarılmıştır. Manşetin içinde yer alan "Macron Avrupa'ya Tehdit" başlıklı haberde ise Cumhurbaşkanlığı İletişim Başkanı Fahrettin Altun'un Fransa Cumhurbaşkanı Macron'a dair açıklamasına yer verilmiştir. Haberde Fransız ürünlerinin neden boykot edilmesi gerektiğine dair herhangi bir açıklamaya yer verilmemiş olup, haberde kaynak olarak kullanılan farklı kurumlardan insanların ifadelerinin bir kısmı bağlamından kopartılarak tırnak işareti kullanılmadan aktarılmıştır. Bu anlamda gazetenin kaynak olarak kullandığı kişilerin söylemleri üzerinden Fransız ürünlerine karşı boykot kararını desteklediği gözlenmiștir. Haberde öne çıkan ana temaya bakıldığında ise “Macron'un gün geçtikçe küstahlaşan faşizmine” yönelik Fransız ürünlerine boykotun nasıl ve ne şekilde yapılması gerektiği düşüncesinin hâkim olduğu görülmüştür. Haberde görsel olarak ellerinde Macron'un yüzünün üstünde ayak izi olan bir afişi ve pankartı taşıyan insanların yer aldığı bir fotoğraf kullanılarak haberin retoriği desteklenmeye çalışılmıştır. Ancak kullanılan görselin hangi kaynaktan alındığını belirten bir ifadenin bulunmadığı görülmüştür. Aynı gün gazetede yer alan "Macron Siyasi Şizofren" başlıklı bir başka haberde ise tematik olarak "Akli Melekelerini Kaybetmiş" ara başlığı kullanılmıştır. Haberin içeriğinde MHP lideri Devlet Bahçeli'nin Fransa Cumhurbaşkanı Macron'u "akli melekelerini kaybetmiş" tanımlamasını tırnak işareti kullanmadan aktarıldığı bulgulanmıştır. "Bu siyasi şizofren ne hakla İslam'ı yapılandırmayı hedef olarak belirlemiştir?..." ifadelerinin ise tırnak işareti kullanılmadan aktarıldığı ve bu bağlamda gazetenin tarafsız bir bakış açısına sahip olmadığı gözlenmiştir. Haber kaynağı olarak Devlet Bahçeli'nin Fransa Cumhurbaşkanı Macron'a yönelik ifadelerinin kullanıldığı haberde, söylemsel çerçeve Bahçeli'nin ifadeleri üzerinden Macron'un "siyasi șizofren” ve "akli melekelerini kaybetmiş" bir insan olarak tanımlaması ile inşa edildiği dikkat çekicidir. Ardalan bilgisinin yer almadığı haberde, Bahçeli'nin ifadelerinin bağlamından kopartıldığı ve haberin retoriğini desteklemek için Bahçeli'nin fotoğrafının kullanıldığı gözlenmiştir. Haberin mikro analizine göre gazetenin bir önceki gün haberin içeriğinde ön plana çıkardığı "boykot çağrısı”nı bu sayıda da devam ettirildiği görülmüştür. Bu bağlamda gazetenin bir önceki güne benzer şekilde haberin genel söylemsel çerçevesini inşa ettiği belirlenmiştir. Haberin içeriğinde betimleyici ifadeler kullanılmış olmakla birlikte; anlaşılır bir üslubun benimsendiği görülmüştür. Gazetenin “islam düşmanlığı ve nefretin Avrupada'ki merkezi haline gelen Fransa", “Macron'un gün geçtikçe küstahlaşan faşizmi” gibi ifadeler ile Fransa ve Fransa Cumhurbaşkanı Macron'u tanımlamayı tercih ettiği gözlenmiştir. Haberin genel söylemsel çerçevesinde ön plana çıkartılan "boykot çağrısı"nın ise bu tanımlamalar doğrultusunda ortaya koyulduğu görülmüştür. Bu boykot çağrısının ise gereklilik kipi ile çekimlenmiş cümle yapıları temelinde aktarıldığı sonucuna varılmıştır.

Yeni Şafak gazetesi 29 Ekim tarihli sayısında gelişmeleri, “Avrupa Barbarlığa Geri Dönüyor” manşeti altında büyük puntolarda aktarmıştır. Haberin spotunda Cumhurbaşkanı Erdoğan'ın Avrupa'daki İslam ve Türk düşmanlığına dair açıklamalarına yer verilmiştir. Gazetenin bir kısmını tırnak işareti kullanarak bir kısmını ise tırnak işareti kullanmadan aktardığı açıklamada, İslam ve Türkiye düşmanlarının 'kin ve nefret bataklığı'nda boğulup gidecekleri” ve "barbarlık dönemine geri gidişinin işaretleri” olduğu ifadelerinin ön plana çıkartıldığı görülmüştür. Manşetten verilen haberin tematik yapı incelemesine göre, haber kaynağı olarak Cumhurbaşkanı Erdoğan'ın açıklamalarının kullanıldığı gözlenmiştir. Haberde tematik olarak "Sessiz Kalırsak Öldük Demektir" ve "Ahlaksız Karikatüre Bakmadım" ara başlıklarına yer verilmiştir ve haberin içeriğinde, Erdoğan'ın Hz. Muhammed'e karşı yapılan saygısızlığa karşı duracağını belirttiği ifadelerine, Charlie Hebdo dergisinde kendisi ile ilgili yayınlanan karikatüre yönelik açıklamalarına yer verilmiştir. Habere konu olan olayın ardalanına dair açıklayıcı bilgilerin yer almadığı haberde, Cumhurbaşkanı Er- 
doğan'ın açıklamaları üzerinden konuya dair bir değerlendirmenin ön plana çıkarıldığı, taraflardan herhangi birinin ifadelerine verilmediği dikkati çekmektedir. Manşetten verilen haberin tematik yapı incelemesine göre gazetenin haber kaynağı olarak Cumhurbaşkanı Erdoğan'ın açıklamalarını kullandığı görülmekle birlikte açıklamalarının belirli bölümlerini vererek bağlamından kopartarak aktardığı belirlenmiştir. Aynı gün gazetede yer alan "Ahlaksı Dergiye Soruşturma", "Macron'u Çizdi İşini Kaybetti”, “Fransa'yı Boykota Tam Destek” ve "Macron'un Diplomatik Taciz Hücresi” başlıklı haberlerde ise manşetteki haberin içeriğini destekleyen ve Avrupa'da özellikle Fransa'da artan İslam ve Türk karşıtlığına dair konular aktarılmıştır. Ancak aktarılan haberlerde, belirtilen olay ve durumların hangi kaynak üzerinden elde edildiğine dair herhangi bir bilgiye yer verilmemiştir. Benzer durumun haberlerde kullanılan görseller içinde söz konusu olduğu görülmüştür. Gazetenin manşetten verdiği haberde ve aynı gün yayınlanan diğer haberlerde ön plana çıkardığı ana temaya bakıldığında ise gazetenin Avrupa'da artan İslam ve Türkiye karşıtlığını "barbarlığa dönüş", "kin ve nefret bataklı̆̆ı" olarak nitelendirdiği, Charlie Hebdo dergisini "ahlaksız" ve "namussuzlar"; yayınlarını ise "ahlaksız" olarak tanımladığı gözlenmiştir. Haberin mikro analizine göre haberde genel olarak aktarım fiillerinin ve abartılı ifade biçimlerinin tercih edildiği görülmüştür. Gazetenin Cumhurbaşkanı Erdoğan'ın açıklamaları üzerinden haberin söylemsel çerçevesini inşa ettiği ve bu doğrultuda konuya dair bakış açısını ortaya koyduğu sonucuna ulaşılmıştır. Bu bağlamda gazetenin Erdoğan'ın ifadeleri üzerinden Avrupa'daki İslam ve Türk düşmanlığını "barbarlığa geri dönüş" olarak tanımladığı, bu düşmanlığı yapanların ise "kin ve nefret bataklığında boğulup gideceğinin" vurgulandığı görülmüștür. Uzun cümlelerin kullanıldığı haberin içeriğinde ayrıca Charlie Hebdo dergisinde $\mathrm{Hz}$. Muhammed'e yönelik yapılan karikatürler, "ahlaksız" olarak nitelendirilmiştir. Gazetenin bu bağlamda nesnel bir bakış açısıyla konuyu ele almadığı, taraflı bir yaklaşım ile olaya yönelik tutumunu ortaya koyduğu bulgulanmıştır.

Gazete 30 Ekim tarihli sayısında gelişmeleri, “Macron'un İstediği Buydu” sürmanşetiyle büyük puntolarda okuyuculara aktarmıştır. Siyah arka fon ile aktarılan haber, Macron'un bir görseli ve "Nefret Veba Gibi Yayılıyor" ifadesi ile başlamaktadır. Tematik olarak spot kullanılan haberde, "Fransa Cumhurbaşkanı Macron'un düşmanlığı ve Müslüman nefreti Avrupa genelinde veba gibi yayılıyor" ifadesi verilmiştir. Bu temelde haberin manşetine ve spotuna bakıldığında, gazetenin nesnel bir bakış açısına sahip olmadığı ve Macron'u hedef alan bir yapıda haberin söylemsel çerçevesini inşa ettiği görülmüştür. Haberin devamında Avrupa ülkelerinden Müslümanlara yönelik saldırı, hakaret ve kapatılan cami haberlerinin geldiği ifade edilmekle birlikte bu bilgilerin hangi kaynaktan alındığına dair bir bilgi aktarılmamıștır. Haberde tematik olarak "Yeni Cadı Avı”, “Dışişleri Saldırıyı Kınıyoruz" ara başlıkları kullanıımıştır. "Yeni Cadı Avı" ara başlığında, Nice şehrinin Belediye Başkanının "Bugün, İslami faşizme yeni kurbanlar vererek çok daha ağır bedeller ödemekteyiz" ifadelerinin "cadı avı" tanımlamasını karşıladığı görülmüştür. Haberde görsel olarak bir binanın önünde kalabalık polis gruplarının olduğu bir fotoğraf kullanılmış olup, görsel "Fransa'da kiliseye saldırı: 3 ölü”, “Fransa'da Cumhurbaşkanı Macron'un başını çektiği ‘'islam ile savaş’ stratejisinin ikinci adımı sahneye konuldu..." ifadeleri ile aktarılmıştır. Haberin genel söylemsel çerçevesine Fransa Cumhurbaşkanı Macron'un İslam'a ve Müslümanlara yönelik “düşmanlığı”nın bir sonucu olarak İslam ve Müslüman karşıtlığının arttığına dair bir düşüncenin hâkim olduğu dikkati çekmektedir. Benzer durum "Carrefour'dan Türkiye'ye Boykot” başlıklı bir diğer haberde de söz konusudur. Söz konusu haberin içeriğinde Fransa Cumhurbaşkanı Macron'un "nefret politikası” sebebiyle boykot başlatıldığı ifade edilirken, S. Arabistan'daki Fransız market zinciri Carrefour'un ise Türkiye'ye karşı boykot başlattığı aktarılmıştır. Haberin mikro analizine göre haberde, şimdiki zaman ile çekimlenmiş cümle yapılarının yanı sıra edilgen çatılı fiiller de kullanılmıştır. Haberde "... sahneye koyuldu”, "boğazları kesildi” gibi edilgen çatılı fiiller kullanılmış olup, "nefret veba gibi yayılıyor”, "cadı avı”, "vahşi saldırı” gibi abartılı ifadelerinde habe- 
rin içeriğinde ön plana çıkartıldığı gözlenmiştir. Gazetenin haberin genel söylemsel çerçevesinde İslam ve Müslüman düşmanlığının, karşıtığının artmasında Macron'u hedef gösteren bir anlatı yapısını tercih ettiği ve bu bağlamda haberin manşetinde, spotunda, içeriğinde bu anlatıyı tamamlayan kelime ve kelime gruplarını tercih ettiği belirlenmiştir. Bu bağlamda "Macron'un istediği buydu”, "Fransa Cumhurbaşkanı Macron'un İslam düşmanlığı ve Müslüman nefreti”, "Macron'un başını çektiği İslam ile savaş stratejisinin ikinci adımı" gibi ifadelerin birbirini destekleyen bir yapıda aktarıldığı tespit edilmiştir.

Yeni Şafak gazetesinin 31 Ekim tarihli sayısında, sayfanın en altında "Irkçı Teröre Karartma" başlıklı bir habere yer verilmiştir. Tematik olarak spot ve ara başlıkların kullanılmadığı haberin içeriğinde, Fransa'nın Nice şehrinde bir kilisede 3 kişinin öldürüldüğü saldırıyı Fransa Cumhurbaşkanı'nın "İslamcı terör” şeklinde ifade ederek tüm Müslümanları hedef aldığı belirtilmiştir. Aynı zamanda saldırının gerçekleştiği gün Afrikalı bir esnafa aşırı sağcı olduğu ifade edilen bir kişinin silah doğrulttuğu ve bu kişinin "psikolojik sorunlarından" dolayı terör kapsamında soruşturulmayacağı aktarılmıştır. Haberin genel söylemsel çerçevesinde bakıldığında konuya dair ardalan bilgisinin yer almadığı, haberin içeriğinde aktarılan olayların bağlamından kopartılarak belirli bir yapı içerisinde verildiği görülmüştür. Haberde ön plana çıkan ana temada ise Fransa'da bir saldırı gerçekleştirildiğinde bunun kolay bir şekilde "islamcı terör" olarak nitelendirilebileceği ifade edilirken, bunun tam tersi bir durum söz konusu olduğunda ise terör kapsamında değerlendirilmeyeceği vurgusu ön plana çıkarılmıştır. Haberin mikro analizine göre haberde, uzun ve açıklayıcı cümle yapılarının tercih edildiği görülmüştür. Haberin manşetinde ön plana çıkan "karartma" ifadesinin, haberin içeriğinde detaylandırılarak netlik kazandırıldığı gözlenmiştir. Ayrıca Fransa Cumhurbaşkanı Macron'un Fransa'da meydana gelen bir olayı "Islamcı terör” olarak nitelendirirken, Fransa'da yaşanan bir başka olayı ise terör kapsamında değerlendirmediği vurgulanmıştır.

\section{Sonuç ve Tartışma}

Bu çalışmada, İslam dinini ve Müslümanları hedef alan İslamofobik söylemlerin ve eylemlerin haberleştirilme sürecinde medyanın nefret söylemini inşa eden, körükleyen, tetikleyen bir yapıya sahip olup olmadığı ortaya koyulmak istenmiştir. Bu kapsam doğrultusunda çalışmada, farklı siyasal tercihlere yönelik yayın yapan Cumhuriyet, Hürriyet, Sabah, Sözcü ve Yeni Şafak gazeteleri ele alınmış olup, gazetelerin İslamofobik söylemleri ve eylemleri aktarırken kullanmış oldukları dil ve söylem pratikleri nefret söylemi bağlamında analiz edilmiştir. Gazetelerin İslamofobi temelli herhangi bir durumu, olayı nasıl haberleştirdiğini, hangi söylemsel pratikler etrafında şekillendirdiğini ortaya koymak için çalışma kapsamına dâhil edilen haberler, Teun van Dijk'ın Söylem Analizi yöntemi kullanılarak incelenmiştir. Ele alınan haberlerin analizleri, makro ve mikro yapı temelinde iki ayrı başlık altında yapılmıştır. Gazeteleri genel olarak değerlendirdiğimizde, Cumhuriyet gazetesinin Türkiye ve Fransa arasında yaşanan gelişmeleri "gerilim" olarak tanımlarken, "yaşanan gerginliğin” sorumlusu olarak Cumhurbaşkanı Recep Tayyip Erdoğan'ın açıklamalarını ön plana çıkardığı görülmüştür. Aynı zamanda gazetenin Charlie Hebdo dergisinde $\mathrm{Hz}$. Muhammed'e yönelik yayınlanan karikatürleri de "gerginliğin" bir süreci olarak nitelendirdiği gözlenmiştir. İncelenen zaman diliminde Hürriyet gazetesi, Fransa Cumhurbaşkanı Emmanuel Macron'u "zihinsel bir tedaviye ihtiyacı olan bir birey" ve "siyasi şizofren" olarak tanımlamıştır. Ancak gazetenin bu tanımlamaları haber kaynağı olarak kullandığı kişilerin açıklamaları üzerinden inşa ettiği sonucuna ulaşılmıştır. Gazetenin yaşanan gelişmeler içerisinde $\mathrm{Hz}$. Muhammed'e ve Cumhurbaşkanı Erdoğan'a karşı yapılan hakaretleri de ön plana çıkardığı gözlenmiştir. Sabah gazetesi, İslamofobik temelli yaşanan gelişmeleri “Avrupa 
faşizmi" ve "islam dinine karşı inşa edilen bir cephe" olarak nitelendirmiş olup, Avrupa'nın bu konu hakkındaki durumunu "tehlikeli gidiş" olarak değerlendirmeyi tercih etmiştir. Gazetenin Avrupa'da İslam ve Müslüman karşıtlığının yükselmesinde başrol olarak Fransız Cumhurbaşkanı Emmanuel Macron'u hedef gösterdiği ve bu doğrultuda haberlerin söylemsel çerçevesini inşa ettiği gözlenmiştir. Bu temelde gazetenin kelime ve cümle yapılarını tercih ettiği, Macron'a yönelik tanımlamaları ve hedef göstermeleri haber kaynağı olarak kullandığı kişilerin açıklamaları üzerinden gerçekleştirdiği ortaya koyulmuştur. Bu doğrultuda gazetenin Macron'u “zat” olarak tanımladığı, İslamofobik karikatürlerin yer aldığı Charlie Hebdo dergisini ise "Fransız paçavrası", "provokatör" ifadeleri ile nitelendirdiği gözlenmiştir. Sözcü gazetesinin ise Fransa Cumhurbaşkanı Macron'u "yalancı" ve "iftiraya sarılan" bir lider olarak tanımladığı görülürken, Fransa'yı "İslam karşıtı söylemleriyle nefret toplayan” ülke olarak nitelendirdiği dikkat çekmektedir. Ancak gazetenin bu tanımlamalarının yanı sıra Cumhurbaşkanı Erdoğan'ın Macron'a yönelik açıklamalarını “çıkışma” ve "yüklenme” olarak değerlendirdiği ve bu bağlamda Erdoğan'ı, açıklamaları ile Macron'a “yüklenen” birisi olarak ön plana çıkardığı gözlenmiştir. Yeni Şafak gazetesinin incelenen tarihler arasında aktardığı haberlerde, haber kaynağı olarak Cumhurbaşkanı Erdoğan'ı kullandığı ve Erdoğan'ın açıklamaları üzerinden haberlerin söylemsel çerçevesini inşa ettiği görülmüştür. Bu bağlamda gazetenin Erdoğan'ın açıklamaları üzerinden Macron'u “zihinsel tedaviye ihtiyacı olan bir birey", "bir vaka" olarak nitelendirdiği, Hollanda milletvekili Wilders'ı ise "ırkçı" ve "milletvekili müsveddesi” şeklinde tanımladığı belirlenmiştir. Gazetenin, İslam ve Türkiye düşmanlarının "kin ve nefret batağında boğulacağını" vurguladığı, İslam ve Türkiye düşmanlığının artmasında ise Macron'un nefret politikasının başı çektiğini ön plana çıkardığı görülmüştür. Sonuç olarak medya kuruluşlarının İslamofobik içerikli olay, durum veya buna bağlı yaşanan gelişmeleri haberleştirirken nefret söyleminin üretilmesine ve meşrulaştırılmasına katkı sağlayan ifade biçimlerini tercih ettiği bulgulanmıştır. Bu bağlamda, medya kuruluşlarının İslamofobik temelli herhangi bir şeyi aktarırken, nesnel bir bakış açısına sahip olmadığı ve farklı söylemsel, dilsel pratikler üzerinden belirli kişi ya da grupları hedef alan nefret söyleminin üretilmesine katkı sağladığı gözlenmiştir. Ele alınan gazeteler genel olarak değerlendirildiğinde, gazetelerin İslamofobik temelli olayları, durumları aktarırken ardalan ve bağlam bilgisini detaylandırmadığı, söz konusu haberlerin içeriklerini tek bir kişinin konuya dair yaptığı değerlendirmeler üzerinden inşa ettiği ve bu kişinin değerlendirmeleri üzerinden nefret söylemi üretiminde bulunduğu tespit edilmiştir. Bu çerçevede gazetelerin haber kaynağı olarak kullandıkları, kişilerin açıklamalarını içselleştirerek okuyuculara yansıtığı belirlenmiştir.

\section{Kaynakça}

Abadi, H. (2018). Countering the Islamophobia industry toward more effective strategies. Nisan 5, 2021 tarihinde https://www.cerisnet.org/sites/default/files/UploadedFiles/cr-countering-the-islamophobia-industry.pdf adresinden alındı

Allen, C. (2010). Islamophobia. England: Ashgate Publishing Limited.

Arslan, D. A. (2019). Dünyada ve Türkiye'de medya ve İslamofobi. Dünya İnsan Bilimleri Dergisi (2), 28-52.

Basit, A. (2018). Racism, Islamophobia and western media: An analysis how western media portrays Muslims and Islam in the west. Muslim Perspectives , 3 (3), 19-35.

Bezci, B. (2017). Avrupa'da göç politikaları, İslamofobi ve aşırı sağın yükselişi. B. Bezci, S. Tauscher ve F. Topal içinde, Avrupa'da göç ve İslamofobi (s. 1-19). Ankara: Karınca Ajans Yayıncılık Matbaacılık.

Bilewicz, M., and Soral, W. (2020). Hate speech epidemic. The dynamic effects of derogatory language on intergroup relations and political radicalization. Political Psychology , 41 (1), 3-33. 
Bodur, H. E. (2017). Batı'da İslam karşıtlığının icat edilmiş dili olarak İslamofobi (çatışmacı sosyolojik perspektif). ilahiyat Akademi (6), 69-86.

Buehler, A. F. (2014). İslamofobi: Batı'nın “karanlık tarafı"nın bir yansıması (Ç. M. Atalay). Ankara Üniversitesi İlahiyat Fakültesi Dergisi , 55 (1), 123-140.

Canatan, K. (2017). "Batı"nın “Doğu”da bir şeytan yaratma girişimi olarak İslamofobi ve anti-islamizm: Tarihsel bir yaklaşım. Ilahiyat Akademi (6), 87-104.

Chaudhari, A., Parseja, A., and Patyal, A. (2020). CNN based hated-o-metter: A hate speech detecting tool. 2020 Third International Conference on Smart Systems and Inventive Technology (ICSSIT) (s. 940-94). Infia: IEEE.

Cohen-Almagor, R. (2018). When a ritual murder occurred at Purim. The harm in hate speech. El profesional de la información , 27 (3), 671-681.

Cotik, V., Debandi, N., Luque, F., Miguel, P., Moro, A., Perez, J. M., et al. (2020). A study of hate speech in social media during the COVID-19 outbreak. Nisan 5, 2021 tarihinde https://rdu.unc.edu.ar/bitstream/handle/11086/16293/a_ study_of_hate_speech_in_social_media_during_the_covid_19_outbreak. pdf? sequence $=2$ \&isAllowed $=y$. adresinden ${ }^{-}$alındı

Er, T. ve Ataman, K. (2008). İslamofobi ve Avrupa'da birlikte yaşama tecrübesi üzerine. Uludağ Üniversitesi Illahiyat Fakültesi Dergisi , 17 (2), 77-770.

Firıncı, Y. (2020). Countering psychological operations and deceptions that indoctrinate anti-islam hate and violence. International Journal of Politics and Security (5), 94-126.

Furlanetto, E., and Mehring, F. (2020). Media agoras: Islamophobia and inter/multimedial dissensus introduction. European Journal of American Studies , 15 (3), 1-9.

Gata, W., and Bayhaqy, A. (2020). Analysis sentiment about Islamophobia when Christchurch attack on social media. TELKOMNIKA Telecommunication, Computing, Electronics and Control , 14 (4), 1819-1827.

Gökmen, H. (2010). Avrupa'da Müslümanlar ve İslamofobi (Hollanda örneği). Kahramanmaraş: Kahramanmaraş Sütçü İmam Üniversitesi Sosyal Bilimler Enstitüsü, Yüksek Lisans Tezi.

Göksu, V. ve Saygılı, R. (2012). Amerikan medyasının İslam algısı. İslamofobi Kolektif Bir Korkunun Anotomisi (s. 91-102). Ankara: Ankamat Yayıncılık.

Gölcü, A. ve Dağlı, A. N. (2017). Haber söyleminde 'öteki’yi aramak: Suriyeli mülteciler örneği. Akdeniz Üniversitesi Illetişim Fakültesi Dergisi, (28), 11-38.

Gölcü, A., Bal, E. ve Karadeniz, B. (2019). Dil ve söylem pratiklerini haber metinlerinde aramak: Yeni Zelanda terör saldırısı örneği. RumeliDE Dil ve Edebiyat Araştırmaları Dergisi, (17), 220-251.

Hajjat, A. (2020). Islamophobia and French academia. Current Sociology , 1-20.

İnal, M. A. (1996). Haberi okumak. İstanbul: Temuçin Yayınları.

Inceoğlu, Y. (2012). Önsöz. Y. Inceoğlu içinde, Nefret Suçları ve Nefret Söylemi (s. 11-23). İstanbul: Ayrıntı Yayınları.

Isasi, A. C., and Juanatey, A. G. (2016). Hate speech in social media: a state-of-the-art review. Nisan 5, 2021 tarihinde https://www.uclg-cisdp.org/sites/default/files/ Hate\%20Speech\%20A\%20State\%200f\%20the\%20Art.pdf adresinden alındı

Kahraman, A. (2012). İslamofobiyi besleyen unsurlardan biri olarak "islam şeriatı" algısı. İslamofobi Kolektif Bir Korkunun Anatomisi (s. 189-201). Ankara: Ankamat Matbaacilık. 
Kalın, ì. (2003). Batı'daki İslam algısının tarihine giriş. Divan: Disiplerarası Çalışmalar Dergisi (15), 1-51.

Karadeniz, B. (2020). Yeni medyada nefret söylemi: Twitter uygulamasında nefret söylemi analizi. Konya: Selçuk Üniversitesi Sosyal Bilimler Enstitüsü, Yüksek Lisans Tezi.

Karaşahan, M. (1994). Medyatik dünya, medyatik köleler. Umran Dergisi, 10-13.

Kepenek, B. (2017). Avrupa'da İslam düşmanlığı ve İslamofobi. B. Bezci, S. Tauscher ve F. Topal içinde, Avrupa'da Göç ve İslamofobi (s. 119-204). Ankara: Karınca Ajans Yayıncilık Matbaacılık.

Kınık, H. ve illter, E. (2019). Müslümanlara yönelik medya algısı: İngiliz basını. Atatürk Üniversitesi İtisadi ve Idari Bilimler Dergisi, 33 (3), 963-976.

Koçer, M. ve Yazıcı, F. (2018). İslamofobinin Charlie Hebdo dergisi Twitter hesabında paylaşılan karikatürler örneğinde incelenmesi. Medya ve Din Araştırmaları Dergisi (MEDIAD), 1 (2), 191-209.

Köker, E. ve Doğanay, Ü. (2010). Türkiye'yi vurdular: Yazılı basının Hrant Dink cinayetini adlandıramaması. A. Çavdar ve A. B. Yıldııım içinde, Nefret Suçları ve Nefret Söylemi (s. 97-118). İstanbul: Hrant Dink Vakfı Yayınları.

Kuş, O. (2021). Kovid-19 salgını ve mültecilere yönelik dijital nefret söylemi: Büyük veri perspektifinden metin madenciliği tekniği ile kullanıcı kaynaklı içeriklerin analizi. TRT Akademi, 6 (11), 107-131.

Obeler, A., and Connelly, K. (2014). Hate speech: A quality of service challenge. 2014 IEEE Conference on e-Learning, e- Management and e-Services (IC3e) (s. 117-121). Australia: IEEE.

Özer, Ö. (2011). Haber söylem ideoloji: Eleştirel haber çözümlemeleri. Konya: Literatürk Yayınları.

Özkaya, E. (1994). İletimden iletişime. Umran Dergisi , 5-9.

Saeed, A. (2019). An overview of Islamophobia as othering. Global Mass Communication Review (GMCR) , 4 (1), 1-9.

Sajid, A. (2005). Islamophobia: A new word for an old fear. 4 5, 2021 tarihinde https:// pij.org/articles/344/islamophobia-a-new-word-for-an-old-fear adresinden alındı

Samur, H. (2017). Avrupa'nın önyargılarının ve çelişkilerinin bir sonucu olarak i̇slamofobi. Yönetim Bilimleri Dergisi , 15 (29), 147-173.

Sarı, E. (2015). Türkiye'de medya okuryazarlığı eğitimi ve nefret söylemi. Iletişim Araştırmaları , $13(2), 33-66$.

Şeker, T. N. ve Şeker, M. (2011). Televizyon haberlerinde söylem: 29 Mart 2009 Yerel Seçimler örneği. Selçuk Üniversitesi Türkiyat Araştırmaları Dergisi (30), 515-522.

The Runnymede Trust. (1997). Islamophobia: A challenge for us all. Nisan 5, 2021 tarihinde https://www.runnymedetrust.org/companies/17/74/Islamophobia-A-Challenge-for-Us-All.html adresinden alındı

Tunçay, E. (2017). Medyada nefret söylemi: Ankara patlaması örneği. Marmara iletişim Dergisi (27), 41-62.

Türkan, H. (2015). Avrupa'da yükselen ayrımcllık nefret, islamofobi ve ırkçılık. İstannul: Uluslararası Hak ỉhlalleri İzleme Merkezi.

van Dijk, T. A. (1988b). News analysis. New Jersey: Lawrence Erlbaum Associates Publishers.

van Dijk, T. A. (1988a). News as discourse. New Jersey: Lawrence Erlbaum Associates Publishers. 
van Dijk, T. A. (1997). The study of discourse. T. A. van Dijk içinde, Discourse as structure and process (volume 1) (p. 1-34). London: Sage Publications.

Weber, A. (2009). Nefret söylemi el kitabı. (M. Çulhaoğlu, Çev.) Avrupa Konseyi Yayınları.

Yapıcı, A. ve Yapıcı, F. (2017). Ön yargı ve ayımcılık bağlamında İslamofobi: Dini-sosyal kimlikler arası ilişkilerde değișim ve süreklilik. Illahiyat Akademi , 5 (6), 1-26.

Yel, A. M. (2018). Medya ve sinemada temsil edilme biçimleriyle İslam karşıtlığı. Medya ve Din Araştırmaları Dergisi (MEDiAD), (1), 5-16.

Yıldız, A. (1994, Mart-Nisan). Çağdaş tiranlık: Medya imparatorluğu. Umran Dergisi, 3-4.

Yilmaz, I. (2016). The nature of Islamophobia: Some key features. D. Pratt, and R. Woodlock içinde, Fear of Muslims? (p. 19-29). Switzerland: Springer International Publishing.

\section{Gazeteler}

Cumhuriyet Gazetesi 24 Ekim - 2 Kasım 2020 tarihli sayıları

Hürriyet Gazetesi 24 Ekim - 2 Kasım 2020 tarihli sayıları

Sabah Gazetesi 24 Ekim - 2 Kasım 2020 tarihli sayıları

Sözcü Gazetesi 24 Ekim - 2 Kasım 2020 tarihli sayıları

Yeni Şafak Gazetesi 24 Ekim - 2 Kasım 2020 tarihli sayıları 


\title{
MEDIAD \\ Medya ve Din Araștırmaları Dergisi | Journal of Media and Religion Studies
}

\section{Islamophobia as a Practice of Hate Speech: The Ways of Reflecting Islamophobic Discourses Rising in France in the Turkish Written Press}

\author{
Şükrü BALCI
}

Betül KARADENIZ

\section{Extended Abstract}

Islamophobia, a phenomenon that has its historical roots in the past, expresses an artificial fear of Islam and Muslims. Although Islamophobia has historical roots, holding Islam members responsible for the $9 / 11$ attacks plays an important role in its construction based on artificial fear. After the September 11 attacks, Islamophobic attitudes and behaviors started to manifest themselves in different ways in the social structure, especially in Europe and America. In this context, Islamophobia has started to appear in different forms such as anger, hatred, marginalization, racism, and hostility targeting the religion of Islam and Muslims in daily life. With the influence of the media, Islamophobia has become widespread, internalized, and legitimized easily. Any negative event about Muslims through the media has begun to be built in a structure that will generalize the religion of Islam and all Muslims. This situation has led to negative consequences, including the identification of Islam with "terror" and the definition of Muslims as "terrorists". In the framework of Islamophobia, which is a phenomenon fueled and spread through the media today, the religion of Islam and Muslims are positioned as "the other" in front of the West, and on this basis, they are portrayed as an enemy. If this situation is shaped based on hate and reflects on various forms of expression, the foundations of hate speech targeting the religion of Islam and Muslims are laid. The media plays a decisive role in the production and transmission of hate speech against Islam and Muslims to the masses. In addition, the media can reproduce hate speech over any Islamophobic subject. In other words, while the media expresses their reaction against any Islamophobic event, they can target certain individuals or groups by producing hate speech.

In line with this scope, the study tried to reveal whether hate speech is produced through the media against Islamophobic discourses targeting the religion of Islam and Muslims. In the study, after the incident of the death of a teacher by decapitating a teacher in France on October 16, 2020, after the French authorities defined the incident as "Islamist terrorism" and the aggressor as "Islamist terrorist", how the Islamophobic discourses targeting Islam and Muslims and the developments after the incident are in the Turkish print media? It is aimed to reveal that it has been handled and transferred. In line with this purpose, the reflection of hate speech practices on the language and discourse of the media organizations with different broadcasting policies in the process of reporting Islamophobic discourses targeting Islam 
and Muslims after the incident in France and the developments experienced were emphasized. The sample of the study was determined as all the front page news published by Cumhuriyet, Hürriyet, Sabah, Sözcü, and Yeni Şafak newspapers regarding the developments after the incident. The news reports of the selected newspapers on the subject between October 24 - November 2, 2020, were handled in the context of hate speech. Within the scope of the study, the headlines of the news, their contents, visuals, and the perspectives of the newspapers regarding the event were analyzed with the discourse analysis method that Teun van Dijk systematized based on two parts, macro, and micro. As a result of the research, it was observed that the examined newspapers produced news in a structure that produced and incited hate speech on a subject shaped based on Islamophobia. In this context, it was seen that Cumhuriyet newspaper preferred to express the rising Islamophobic rhetoric and spreading problems in France as "tension" and emphasized that the statements of President Recep Tayyip Erdogan were effective in the formation of this "tension". It has been observed that Hürriyet newspaper targets the President of France, Emmanuel Macron, and defines Macron as a "political schizophrenic", "a person in need of mental treatment". Sabah newspaper of France, and developments that shaped based on Islamophobia in Turkey, "European fascism" and "a facade built against Islam" are announced and as responsible for the proliferation of Islam and Muslim opposition in Europe, French President Emmanuel Macron target shown and on this basis, It was observed that he preferred to describe Charlie Hebdo magazine, which he described as "the person" and contains Islamophobic cartoons, as "French rag", "provocateur". Sözcü newspaper handled the issue within the framework of a negative perspective towards France and President Macron. While the Sözcü newspaper described Macron as a "liar" and "slandered" leader, it preferred to express France as a country "collecting hate with its anti-Islamic rhetoric". In addition, it was observed that the newspaper evaluated President Erdogan's statements against Macron as "outcast" and "burdened" and defined President Erdogan as someone "loaded" on Macron through these statements. Yeni Şafak newspaper, on the other hand, refers to French President Macron as "an individual in need of mental treatment" and "a case" through the statements of President Erdogan, and preferred to describe the Dutch deputy Wilders as "racist" and "parliamentary draft". has been seen. When we evaluate the newspapers in general, it is observed that media organizations adopting different broadcasting policies use forms of expression that generate and fuel hate speech while dealing with and reporting an Islamophobic-based event. In this framework, it was observed that the newspapers examined within the scope of the study did not have an objective perspective while conveying Islamophobic-based issues and that they built news texts in a structure that contributed to the legitimization of hate speech.

\section{Araştırmacıların Katkı Oranı Beyanı / Contribution of Authors \\ Yazarların çalışmadaki katkı oranları eşittir. \\ The authors' contribution rates in the study are equal. $* * * * * * * *$}

Çıkar Çatışması Beyanı / Conflict of Interest

Çalışma kapsamında herhangi bir kurum veya kişi ile çıkar çatışması bulunmamaktadır. There is no conflict of interest with any institution or person within the scope of the study. $* * * * * * * *$

\section{Intihal Politikası Beyanı / Plagiarism Policy}

Bu makale iThenticate yazılımıyla taranmıştır. İntihal tespit edilmemiştir.

This article has been scanned by iThenticate. No plagiarism was detected. $* * * * * * * *$

Bilimsel Araştırma ve Yayın Etiği Beyanı / Scientific Research and Publication Ethics Statement Bu çalışmada "Yükseköğretim Kurumları Bilimsel Araştırma ve Yayın Etiği Yönergesi" kapsamındaki kurallara uyulmuştur.

In this study, the rules stated in the "Higher Education Institutions Scientific Research and Publication Ethics Directive" were followed. 